\title{
On the Structure and Affinities of the Palaeozoic Seeds of the Conostoma Group.
}

BY

\author{
F. W. OLIVER, F.R.S. \\ Professor of Botany in the University of London,
}

AND

E. J. SALISBURY, B.SC.

Quain Student of Botany in University College, London.

With Plates I-III and thirteen Figures in the Text.

Contents.

I. INTRODUCTION • • . . . . 2

II. Conostoma oblongum . • • 5

I. Enumeration of Specimens $\quad 5$

2. General Features. • • . 7

3. The Testa . . . . . . 9

4. The Vascular System . . . I3

5. The Soft Integument . . . I3

6. The 'Blow-off' Layer . . . I4

7. The Nucellus . . . . . I6

8. The Lagenostome and Plinth . I6

III. Conostoma ANGLO-GERMANICUM 23

I. Enumeration of Specimens . 23

2. General Features . . . 24

3. The Testa . . . . . 28

4. The Vascular Systern . . 29

5. The Nucellus . . . . . 30

6. The Lagenostome . . . 30

7. The Plinth. . . . . $3^{\mathbf{I}}$
PAGE

IV. COMPARISON WITH RELATED TYPES . • . . . . . . $3 \mathbf{I}$

I. With Gnetopsis elliptica . . 3 r

2. With Physostoma . . . 35

3. With Lagenostoma . • • 35

V. Classification and Diagnoses . 36

VI. The Pollination Mechanisms of the Lagenostomales • • $3^{8}$

VII. General Discussion on the Testa . . . . . $4 \mathrm{I}$

VIII. Conclusion ANd Summary • 45

IX. Glossary of Terms employed • 47

X. Literature cited - . . . $4^{8}$

XI. Explanation of Plates I-III . $4^{8}$

\section{INDEX TO TEXT-FIGURES.}

I. Plottings of sections of C.oblongum on vertical diagram... . . .

2. Plottings of $C$. oblongum on transverse diagram . . . . . .

3. Restorations of $C$. oblongum . . .

4. Testa of $C$. oblongum cut obliquely .

5. Restoration of the lagenostome of C. oblongum . . . . . . .

6. Sculptured cells of lagenostome of C.oblongum ...... . . 18

7. Restorations of the plinth and contents
PAGE

8. Longitudinal and transrerse plottings of $C$. anglo-germanicum . . . 25

9. Vertical restorations of $C$. anglo-germanicum . . . . . . . 26

I0. Transverse restorations of $C$. anglogermanicum . . . . . . 27

II. Hypothetical restoration of Gnetopsis elliptica • . . • . . . 34

I2. 'Pollen-chambers' of Lagenost omales 13. Transverse restorations of apices of Physostoma and the two species of Conostoma........ 42

[Annals of Botany, Vo1. XXV. No. XCVII. January, IgIr.] 


\section{INTRODUCTION.}

$7 \mathrm{HE}$ object of the following paper is a twofold one. In the first place, to present a detailed account of a small and homogeneous group of palaeozoic seeds, the hitherto practically unknown Conostoma group; in the second place, closely to compare these newly-described seeds with forms already familiar, viz. with the Pteridospermic seeds, Lagenostoma and Physostoma, and with Gnetopsis. Thanks to the kindness of Professor C. E. Bertrand and the extreme courtesy of Professor H. Lecomte of the Musée d'Histoire Naturelle at Paris, we have had at our disposal for comparison the superb and unique series of type specimens of Gnetopsis elliptica from the Renault collection. We are thus in a position to state our conclusions after consulting at first hand the whole of the preparations which bear on the subject.

The little-known genus Conostoma was founded by Williamson in $1877^{1}$ for the reception of three of the smaller palaeozoic seeds, viz. C. oblongum, from the Gannister beds of the Lancashire coalfields, and $C$. orale and intermedium from the Calciferous Sandstone Series of Burntisland. With the Burntisland seeds we have no concern here, as they are under reinvestigation at the hands of Miss Benson. We understand, however, that the two species are not really distinct and are being reduced to one, for the reception of which, in view of its structural peculiarities, Miss Benson is founding a new genus to be named Sphaerostoma.

Conostoma oblongum is one of the very rarest of Coal Measure seeds, and apart from a passing notice by one of us, ${ }^{2}$ has not, so far as we know, found mention in the literature of Palaeobotany since the publication of Williamson's brief description in 1877 . At intervals during the last nine years, however, specimens from Mr. James Lomax have been added to the University College Collection; these, together with one from $\mathrm{Mr}$. W. Hemingway and two kindly lent us for description by Mr. D. M. S. Watson, form the whole of the new material at our disposal. One of Williamson's two type specimens is available for reference in the Williamson Collection ; ${ }^{3}$ his other type, the more valuable of the two, we have been unable to consult. It is probably in the Butterworth Collection, but we have not been successful in tracing the section.

During the course of our reinvestigation of Conostoma oblongum occasional sections of what appears to be a closely allied but undescribed species came into our hands. The first sections (received in 1904) were from Shore and Dulesgate; more recently a series of four transverse sections of a single

1 W. C. Williamson : On the Organization, \&c., pt. viii, Ferns, Gymnospermous stems and seeds. Phil. Trans., 1877 , p. 243.

${ }^{2}$ F. W. Oliver : On Physostoma elegans. Ann. of Bot., vol. xxiii, pp. 99, 105, and I10.

3 Nos. 1443 and 1444. 
specimen were cut from a small block obtained many years ago by Dr. Kidston at Langendreer in Westphalia, and again this year another specimen has been found at Shore.

These specimens by themselves would have been inadequate for satisfactory description had they not been supplemented by Dr. J. W. Jongmans of Leiden, who, hearing that we were at work upon Conostoma, placed at our disposal with the greatest liberality both the sections from Duisburg, in Rheinpreussen, that were already in his collection, and uncut blocks from the same locality which have yielded us additional specimens of this undescribed seed. Thus it comes about that whilst the earliest and latest specimens are from Shore, Littleborough, the majority, and certainly the most valuable preparations, are derived from the nodules of Langendreer and Rheinpreussen. In view of this double source of type specimens we propose to name our new seed Conostoma anglo-germanicum.

The two members of the Conostoma group with which we deal fully in this paper are C.oblongum and C. anglo-germanicum.

Before proceeding to the detailed descriptions, it will be convenient briefly to outline the methods on which we have placed reliance in the reconstruction of these two seeds.

With objects preserved as petrifications in coal-balls accurate knowledge of form mainly depends on the interpretation of sections cut at different heights and at varying angles. When the object under investigation is of convenient size it is usually possible to procure series of sections cut parallel to one another at regular intervals. Such series are readily drawn or photographed, and models in wax or other plastic material constructed, so that the object can be faithfully reproduced on any desired scale. In the case of small objects only a few millimetres in length and of complex structure, like our seeds, this direct method is not available. For in virtue of its smallness such an object is apt to evade detection in the matrix until a chance section reveals its presence. Moreover, for the same reason, even when detected before cutting, its very smallness places a limit to the number of sections which can be cut through it. In other words, the ordinary methods of the palaeobotanist break down when applied to the investigation of minute objects.

Our experience with $C$.oblongum affords a good example of what must be a common predicament. In all, sixteen sections were available, cut at varying angles through sixteen distinct specimens. Of these sixteen sections fourteen were oblique longitudinal sections through the body of the seed, one a transverse oblique, and one transverse across the stalk.

In one respect our task was sensibly lightened at the outset, for, owing to the histological peculiarities of the testa, no serious doubt was ever entertained as to whether a given section belonged to our seed or net. 
Our object was to reconstruct our seed in the form of an enlarged model upon which the planes of the various sections could be plotted, and then, by cutting along the appropriate plane, any given section could be reproduced. We began by plotting a sketch of a provisional median longitudinal section, using for the purpose such data, not exaggerated by obliquity of plane, as could be derived from the most favourable preparations available. As each successive section was handled the sketch of course underwent gradual modification.

Thus, every section contributed something; and in the end, after repeated correction, a sketch was obtained upon which all our sections could be approximately plotted. This 'ideal' section could at best be no more than an approximation, because the sections upon which it was founded had been cut from a large number of specimens which from the nature of the case would show some variability of dimensions, even if the extreme assumption were made that they all belonged to the same developmental phase.

With the 'ideal' longitudinal section as basis, a model of the halved seed on a scale of $40: I$ was constructed in papier mâché, together with a number of identical plasticine models of the complete seed on the same scale from which to reproduce our original sections. The papier mâché model, which gave internal details as well as surface relief, was of course of great utility in orientating the planes to be followed in sectioning the plasticine models. For accuracy in cutting the sections of the models a simple guillotine or microtome was devised. It consisted essentially of an oblong frame hinged at its narrower end on to a board which formed the support on which the model was placed for sectioning. The plasticine model projected through this frame (which could be adjusted at any required angle), and the section was cut by sliding a taut copper wire along the smooth upper surface of the frame. By the use of this contrivance we have found it possible to reproduce in essentials any given section of our series. Repeated trials have often been necessary, for the slightest differences in either the plane of cutting or in the relation of the point of entrance of the stretched wire to the surface bring about very marked differences in the contours of the sections produced. In other words, form, as expressed in a section, is an extremely sensitive thing, subject to very striking fluctuations from apparently trivial causes. What is true of the form of an object like a seed holds also in the case of minute histological detail.

When reliance has to be placed on the study of oblique sections (an everyday occurrence in palaeobotanical work) we have found wrong inferences, as to the three-dimensional figure of the elements cut, to be almost inevitable without checking by means of models.

In the case of the seeds described in this paper, the plotting of almost every section has been verified by following the method outlined above, and 
as a result we are able to publish our results and reconstructions with much more confidence than would otherwise have been the case.

We now pass on to the detailed description of Conostoma oblongum and anglo-germanicum. This is followed by comparisons with allied seeds and by a series of diagnoses, including those of the genus and species; the paper concludes with a general discussion on points arising out of the work.

\section{CONOSTOMA OBLONGUM. \\ I. Enumeration of specimens.}

Our account of this seed is based on the following preparations, all from the seam nodules of the Lower Coal Measures of Lancashire and Yorkshire.

\section{University College Collection.}

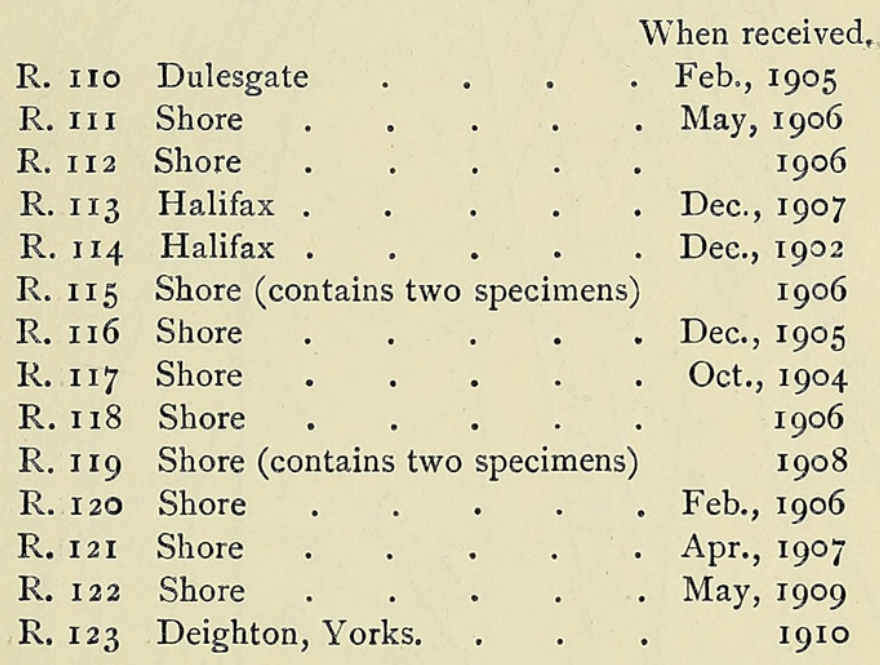

Mr. D. M. S. Watson's Collection.

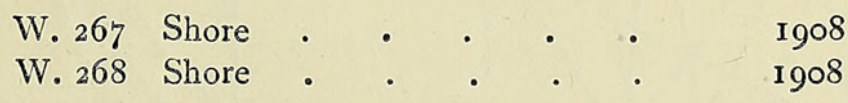

Williamson Collection.

Nos. 1443 and 1444 Oldham.

The only other specimen that we know of is that figured by Williamson in his 8th Memoir (I877), Pl. XII, Fig. 86. It was lent him by the late John Butterworth, and has not been seen by us.

The positions of these sections, other than those in the Williamson Collection, are plotted in relation to the median longitudinal section of the seed in Text-fig. I, and in relation to the transverse section just below the level of the tapetal septum in Text-fig. 2. 


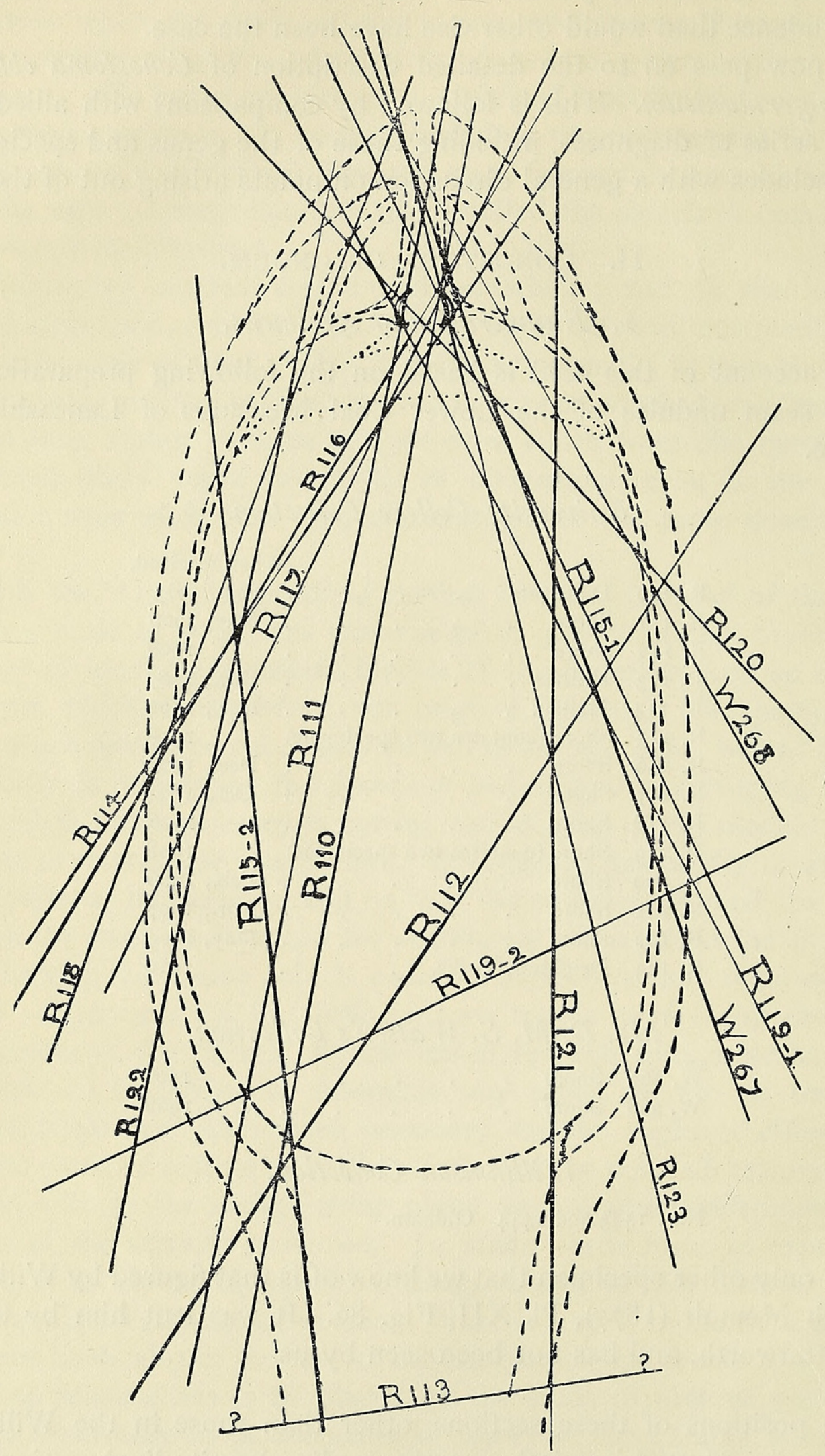

TEXT-FIG. I. Diagrammatic sketch of a median longitudinal section of Conostoma oblongum upon which are plotted the approximate positions of the planes of section of all preparations used in this paper. The reference letters and numbers given with each section on the figure are the designations under which the preparations are cited in the explanation to the plates. $\mathrm{R}=$ University College Collection; W = Mr. D. M. S. Watson's Collection. 


\section{General Features.}

Conostoma oblongum is a straight, cylindrical, or obscurely prism-shaped seed, tapering gently to a blunt point above, where it is perforated by the micropyle, whilst below, in the chalazal region, it narrowed more abruptly to its insertion on a fairly thick stalk (Text-fig. 3 and P1. I, Fig. I). The average length was $5 \mathrm{~mm}$. and the maximum diameter $2.3 \mathrm{~mm}$. The seed-base bore six salient ridges, which, running up from the peduncle, died out almost at once, reappearing, however, at the apex to form a crown around the micropyle. On the main body of the seed these ridges are represented by a slight angling of the surface, hardly prominent enough to be called ribbing. Perhaps the most interesting feature in the form of this

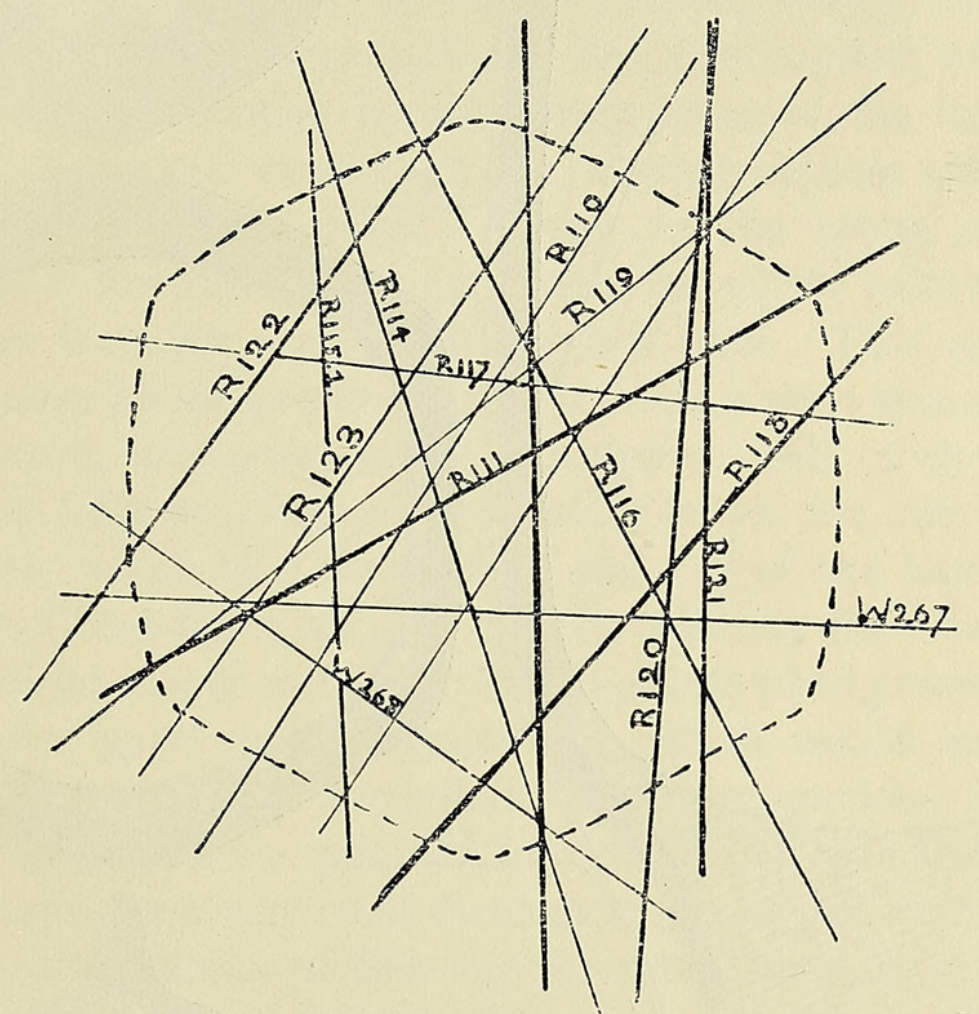

TEXT-FIG. 2. Conostoma oblongum. Diagrammatic transverse section of seed cut about I mm. below the lagenostome, with plottings of the sections used. References as in Text-fig. I.

seed is the existence of a slight bilateral symmetry, only trifling in amount, but sufficient to rank it technically with the 'platysperms' (Text-fig. 3, C).

The internal organization of the seed resembles that of a Lagenostoma in so far as the more general relations of integument, nucellus, and pollenchamber are concerned, though it differs from that genus in many important particulars. As in Lagenostoma, the single integument or testa is coalescent with the nucellus from the seed-base to within about $\mathrm{I} \cdot 3 \mathrm{~mm}$. of the apex. It formed a hard shell to the seed about O.I mm. in thickness, and exhibited a very characteristic histological structure. At the summit it undergoes marked thickening to form a conical 'canopy' surrounding the micropyle. 


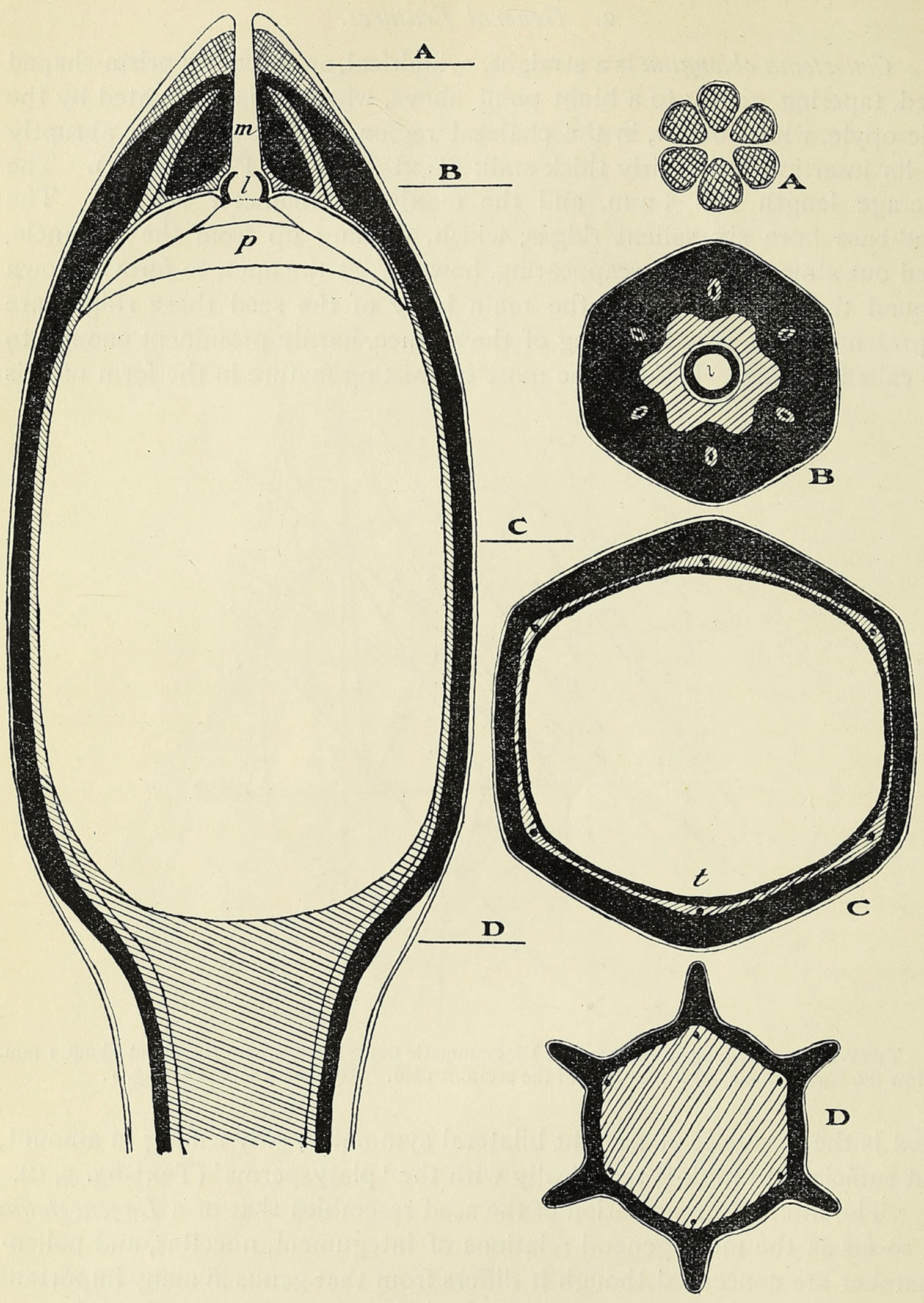

TeXt-FIG. 3. Conostoma oblongum. Restorations. The longitudinal section passes through two opposing ribs; in the middle region the vascular bundles and nucellar wall are represented by a single line except in the transverse sections of the latter; $\mathrm{A}$ and $\mathrm{D}$ are in part hypothetical. The hard testa is in black, parenchymatous tissue shaded, and the soft apical tissue cross-hatched. The ribs and 'blow-off' layer are in white and the lagenostome in black. $m$, micropyle; $l$, lagenostome ; $p$, plinth; $t$, tapetum (omitted from longitudinal section). $\times$ about 25. 
The canopy shows conspicuous lobing, each of the six lobes corresponding to a ridge. The six vascular strands which enter the seed at the chalaza traverse the soft lining of the hard shell of the testa below the ridges and angles, and, continuing to the apex, enter the lobes of the canopy. The surface layer of the seed appears to have undergone mucilaginous degeneration, thus recalling the condition of Lagenostoma. Curiously enough, the actual tip of the seed was succulent, thus contrasting in a striking way with the otherwise sclerotic texture of the integument. This unique feature may well have been correlated with secretory activity at the moment of pollen reception.

The nucellus, which, as usual, stood erect in the axis of the seed, had a length of $3.7 \mathrm{~mm}$. over all. Its lower $3.1 \mathrm{~mm}$., coalescent throughout with the testa, were occupied by the megaspore cavity, which possessed a well-marked tapetal lining or jacket. The free summit of the nucellus, which was closely ensheathed by the lining layer of the integument, was dome-shaped, the dome resting on the tapetal septum which stretched across the nucellus at this level. Above, in the centre of the convex extremity, was a low depression or dimple on which rested the smallest pollen-chamber we have seen in an English seed. This pollen-chamber -or lagenostome, as we prefer to call it-was a tiny, truncated, globular body, open above, and possessed a one-layered wall of characteristically sculptured cells. Its mouth lay immediately below the micropylar tube of the integument, which was clamped to the rim of the lagenostome by a ring-like flange (Text-fig. $5, u f .$, p. I 7 ). In this way the efficient transport of pollen would be amply secured. Pollen-grains when present in the seed have never been found in the lagenostome, which would appear to have served in this case merely as a vestibule to a more spacious lower chamber occupying the interior of the plinth. Into this lower chamber the unusually large pollen-grains were conveyed through the collapse of the floor of the lagenostome. The details of this curious mechanism, so far as we apprehend them, will be fully set forth in the sequel.

The main points in the structure of this interesting seed which merit full description are (I) the testa with its wings, succulent tip, and highly specialized micropyle; (2) the free part of the nucellus closely invested by the lining of the integument and consisting of a two-storied appliance for the reception and maturation of the pollen.

We embody in the accompanying Text-fig. 3 an attempt to reconstruct the median longitudinal section of this seed, together with transverse reconstructions at the several heights indicated.

\section{The Testa.}

The hard part of the testa which gave form to the seed was of a rounded, hexagonal shape, tapering with a steep curve towards the micro- 
pyle, and passing into the stalk below more abruptly. Thus, disregarding the peduncle, the seed, as seen in longitudinal section, was approximately boat-shaped-the apex representing the prow and the base the stern (R. II I, Pl. I, Fig. I).

There is only a single transverse section, somewhat distorted in form, owing to its obliquity both to the axis of the seed and to the two ridges first cut ; but if reliance can be placed on this solitary section, the seed was flattened, to a very slight extent, in a plane passing symmetrically between the angles, two of which were thus rendered more obtuse (Text-fig. 3, C). At these angles the sclerotesta was thickest, whilst it was thinnest at the other four (R. II9, 2, Pl. I, Fig. 5, ma., mi.). At the apex the angling of the middle region passes into definite ridges which end around the micropyle in six not very prominent lobes (Text-fig. 3, A).

In the basipetal direction the angles develop as prominent ridges (R. I IO, Pl. I, Fig. 4) and must have extended downwards, giving a winged

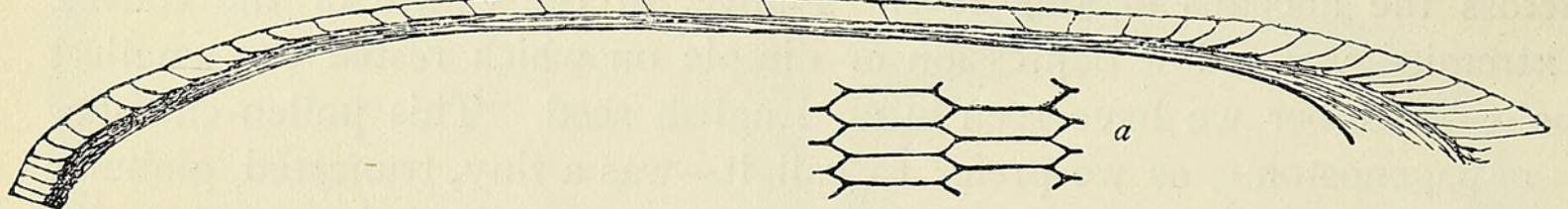

TEXT-FIG. 4. Cells of palisade layer of the testa cut obliquely, showing the forward slope at the apex and the backward slope at the base (left of fig.). R. I22. a, cells of testa in surface view.

character to the seed stalk. (In the instance referred to they are exaggerated by reason of the obliquity of the plane of section.) Although six ridges appear to have been the general rule, variations, which are so marked a feature of the ribbing in Physostoma, no doubt occurred, if only in the direction of increase. The instance is shown in R. IIO, Pl. I, Fig. IO, $r^{7}$, where a seventh rib is seen on the left. In one other case, although the number of ribs remains constant, two of them were abnormally close together.

The internal form of the testa was, in the main body of the seed, similar to that of the exterior. The absence of transverse sections at the base leaves the lower limits of the interior doubtful; at the apex the cavity was dome-shaped, passing into the funnel-like lower end of the micropyle. The dome-shaped apex of the cavity and the acute apex of the exterior thus rendered the testa around the micropyle of considerable thickness $(0.57 \mathrm{~mm}$.) as compared with that of the general body of the seed (0.1 $3 \mathrm{~mm}$.).

In detail, the testa, like that of Lagenostoma Lomaxii, consisted of two kinds of elements, viz. an outer palisade layer and an inner hypoderm. Seen in transverse section the palisade layer presents the form of a continuous investment of radially elongated elements about $70 \mu$ in 
width, whilst near the apex it attains a much greater radial thickness (I I4 $\mu$ ).

The vertical measurement appears to vary considerably, reaching a maximum of about $3^{2} 3 \mu$ in the body of the seed, though adjacent elements cut in the same sense may scarcely reach a quarter of that length. Where the plane of section passes through the curved surfaces of the apex and base, the cells of this layer appear to curve respectively forwards and backwards (Text-fig. 4). Since tangential sections of this layer are wanting, no direct evidence is available as to their external form ; but the appearances described can be satisfactorily explained if we assume the exterior wall to have been a hexagon, in which the sides parallel to the main axis of the seed were longest, and that these cells were arranged in vertical rows (Text-fig. 4, a). Models based on these assumptions, when cut, reproduced with striking fidelity the appearances in the various sections. The invariable obliquity of our preparations will account for the variations of the palisade cells with regard to their vertical dimensions; the maximum will correspond to cells cut in the direction of the long axis of the hexagon, and the minimum to cells cut across the corners.

If a cylinder with longitudinal ribs be cut obliquely it will be found that the ribs appear in the sections to slope forwards at the apex and backwards near the base; this is exactly what we find to be the case with the palisade cells; though here the effect is exaggerated both by their tapering ends and the fact that their outer surfaces are slightly more extensive than their inner. Similarly in the oblique transverse section where the palisade cells are cut through their tapering ends, these show varied trapezial forms, in some places even appearing two-layered.

The carbonized contents of these cells are usually of a uniform dense brown with much lighter or almost colourless walls. In some specimens the cells near the apex show a dark body occupying a nearly central position and surrounded by a lighter portion resembling a vacuole. In general, they resemble the structures seen in the cells of the testa of Stephanospermum, only far less well defined (R. I I 4, Pl. I, Fig. 2, $t$ ).

Abutting internally upon the palisade cells were three to four layers of fibrous elements constituting the hypoderm ; these were ellipsoidal in transverse section, the flattening being in the radial direction. So far as can be judged from oblique sections, their length varied considerably. In the body of the seed this layer reached a thickness of from $57-76 \mu$, and if the single transverse section is to be relied upon, was thickest at the two major angles and thinnest opposite the four minor. It is chiefly due to increase of this tissue that the hard testa attains its greater thickness around the micropyle. In contents and nature of the cell-wall the elements of this layer resemble those of the palisade. The sections all show the testa cut obliquely, the 
most nearly vertical being R. I I I, Pl. I, Fig. I. The others fall into two categories with regard to their direction, viz. :-

I. Sections in which the plane of symmetry passes through a rib or angle (e. g. R. IIO, P1. I, Fig. 10) will taper above and below-the two ends appearing longer and more pointed as the plane of section approaches the vertical, shorter and more rounded as it approaches the transverse.

2. Those in which the plane of symmetry falls between two ribs, the sections appearing boat to coffin shaped according as they pass through the apex or not.

Asymmetrical variations of these two types are the rule, due to the median plane of the section falling between the planes of symmetry (the median plane being that radial plane of the seed which is cut at right angles), or more strictly-regarded as variations of these two groups-due to obliquity of the plane of section to one of these planes of symmetry.

Section R. II9, I (Pl. I, Fig. I I) is a good example of such a variation of the second type. The outline is roughly that of a coffin with sloping ends, the upper half foreshortened owing to the tapering of the apex; as will be seen from the plotting on the transverse diagram (Text-fig. 2 ) the plane of section stands asymmetrically with regard to the two ribs first cut $\left(r^{1}\right.$ and $\left.r^{2}\right)$. For convenience of description, such sections may be termed doubly oblique. In the case of a perfectly cylindrical seed doubly oblique sections are not possible, since the plane of any section is always at right angles to a plane of symmetry. In a ribbed seed, the number of planes of symmetry being only twice that of the ribs, where these, as in the present instance, are few, it is only rarely that a section presents a regular outline.

It appears highly probable that sclerization of the hard testa took place in an acropetal direction. This is suggested by two of the seeds which on general grounds we regard as immature. In the first of these (R. I 22, Pl. I, Fig. 3) the soft-celled tissue (s.t.) which constituted the apical cap is not sharply delimited from the hard tissue below $\left(t_{0}\right)$, as is the case in the mature condition, where the demarcation was sufficiently abrupt to have fissured, in some cases, along this line (W. 267, Pl. I, Fig. 8, s.t.). This seed (R. I 22) would furthermore appear to be young, since the 'blowoff' layer is mostly in situ, and also the plinth, which having regard to the plane of section should have been cut across, is not present-a fact which seems to indicate the later development of this structure.

The second example of a young seed (R. II4) also shows less sclerization of the testa cells-their contents, usually so obscure, being here comparatively well defined (P1. I, Fig. 2). The presence of the pad of tissue beneath the lagenostome with well-preserved cells $(l s$.$) , the exhibition$ of cellular structure by the integumental lining, and a plinth only half the height of those in the mature seeds, all seem to point in the same direction. 


\section{The Vascular System.}

Corresponding in position to the six ribs of the testa were six bundles which occupied the internal angles. These passed up just outside the nucellus till they reached a level slightly above the base of the lagenostome, where they turned upwards and entered the sclerotesta, accompanied by a strand of soft-celled parenchymatous tissue (R. II7, Pl. II, Fig. I6, loc.) ; thence they again curved inwards, probably ending at the limit of the hard testa close to the micropyle; here the accompanying parenchyma, which gradually narrows towards the apex, dies out (Text-fig. 3, between B and A).

Around the micropyle the hard testa was slightly lobed, the lobes corresponding in number and position to the vascular strands within; to this lobing is due the internal asymmetry of the apex seen in some of the sections where they pass through a ridge on one side of the micropyle and through a 'furrow' on the other (R. IIO, Pl. II, Fig. I4; R. I23, Pl. II, Fig. 19, i.r.).

The apex of the hard testa in Conostoma was therefore very like the canopy of Lagenostoma Lomaxii, where likewise the lobes corresponded in number and position to the vascular bundles which passed into them. They did not, however, agree in position with the external ridging of the apex, which, as has been pointed out before, ${ }^{1}$ was associated with the radial septa. The chief point of difference in Conostoma lies in the reduction of the soft tissue which occupied the loculi of the canopy to mere strands accompanying the bundles. The vascular bundles themselves consisted of four to five elements (each about Io $\mu$ across) with delicate scalariform thickenings which occasionally exhibited fusion between adjacent bars.

\section{The Soft Integument.}

Surmounting the apex of the hard testa was a cap of soft-celled tissue (R. 122, Pl. I, Fig. 3, s.t.) which was thickest around the micropyle, where it formed six free lobes (Mr. Watson's specimen 268, Pl. II, Fig. I2, l.) corresponding to the obscure lobing of the hard tissue below, and thinned out in the basipetal direction, ending just above the shoulder of the seed (Text-fig. 3). The only evidence that the vascular supply extended into this region is a very doubtful vascular bundle in one of the preparations. This soft tissue may have been of a secretory nature, supplying in part the necessary fluid for the process of pollination, by furnishing a drop mechanism as in Taxus. The specialized epidermis around the micropyle, to be described later, somewhat resembles the protective epidermis

1 Oliver: On Physostoma. Ann. of Bot., vol. xxiii, p. I05. 
('lip') surrounding the glands of Polygonum, \&c., and may even have served a similar purpose. ${ }^{1}$

Lining the micropyle and continuous with this soft tissue was a single layer of cells, of which only the membrane forming the micropylar tube is preserved (R. III, Pl. I, Fig. 7, m.m.). This latter consists of several tiers of longitudinally elongated elements, which here and there show faint spiral markings; the cells of each tier are of approximately equal length, and, in the middle region, stand directly above those of the tier below. In width they were nearly the same throughout $(I 7 \mu)$, the increased circumference of the micropyle at the base entailing a corresponding increase in their number. At the level of the lagenostome this lining layer of cells suddenly thickened to form a triangular flange, which rested on the upper edge of that organ. A similar flange occupied the shallow sinus where the lagenostome rested upon the plinth. In section the flanges appear as angular projections into the micropyle (R. 117, Pl. II, Fig. I8, u.f. and l.f.). Below the lagenostome the membrane closely ensheathed the dome-shaped plinth, at the base of which the nucellus and integument become fused. In two of the sections the sinus between this membrane and the plinth is seen cut across at the base (R. IIC, Pl. II, Fig. I4, s., and R. 117, P1. II, Fig. 16, s.). Below this point the nucellus and testa were connected by soft-celled tissue, through which the vascular bundles passed. In section R. II4 (P1. I, Fig. 2, pl.j.) the single layer of cells forming the lining membrane of the micropyle is seen cut across between the flanges. From this we see that the lagenostome and plinth, although free, were closely ensheathed by the integumental membrane, which by means of the flanges held the lagenostome in a tightly fitting socket, thus ensuring perfect continuity between the passage of the micropyle and the cavity of the lagenostome; to such an extent was this the case that the contraction of the nucellus previous to fossilization, which usually takes place, has not only caused the lagenostome to descend, but has in some cases brought down the micropylar tube with it, causing rupture near the apex (R. I I , Pl. I, Fig. 7). So long as these were the only sections available, the tube appeared to belong to the lagenostome, but the sections which have more recently come to hand show clearly that its true nature is integumental (Watson's 268, Pl. II, Fig. I2, m.m., and R. 123, P1. II, Fig. 19, m.f.), as the continuity with the soft tissue at the apex is completely shown.

\section{The 'Blow-off' Layer.}

Investing the whole external surface of the seed was a differentiated epidermis, which we shall term the 'blow-off' layer. This, together with

1 E. J. Salisbury: On the Extrafloral Nectaries of the Genus Polygomum. Ann. of Bot., vol. xxiii, I909, p. 239 . 
the soft-celled tissue of the apex, formed a kind of sarcotesta around the seed. The 'blow-off' layer consisted of longitudinally elongated cells with an almost uniform radial dimension of about $20 \mu$. Near the apex, however, they reached a maximum of about $80 \mu$. These cells, as preserved, stand in marked contrast with the palisade cells upon which they rest. Their interior is almost colourless and their walls are dark and slightly thicker towards the exterior. Just below the apex of the seed the cells of this layer reached a maximum radial extension (Watson's specimen 268, Pl. II, Fig. I 2, bl.), bevelling off suddenly towards the micropyle, so that the extreme end of the seed was covered by an undifferentiated epidermis.

The chief point of interest is the exfoliation which the 'blow-off' exhibits : in only one other section besides W. 268 has it remained in situ (R. I 22, P1. I, Fig. 3, 6l.). Elsewhere, the layer stands away from the hard testa as if forced off, and in most cases only the basal portions of the radial walls remain to indicate its former presence. These latter appear as projecting pegs from the margin of the testa, to which they give a crenated appearance (R. IIO, Pl. I, Fig. 4, bl.zv.)

The method by which this exfoliation took place is shown in R. III (P1. II, Fig. I 3, pe.) near the apex, where the cuticle-like layer, formed by the outer walls, is raised up by cones of mucilage which bear a remarkable resemblance to those already described for Lagenostoma Lomaxii. ${ }^{1}$ But whereas the cell-walls in Lagenostoma were raised up as separate entities, in Conostoma they formed a continuous layer, which was removed as a whole, although it underwent fission, due to its rigidity and lack of elasticity, points well shown in one section (R. II6, Pl. I, Fig. 6, bl.) where the exfoliated 'blow-off' at the apex still retains the lobing of the tissue beneath, but, owing to the increased circumference, has fissured along the grooves.

A section which is perhaps correctly allocated to this seed, viz. R. II 3 (P1. I, Fig. 9), is presumably an oblique transverse section passing through the stalk. It was winged with a central cavity (c.s.), probably lysigenetic, and a narrow, angled band of hard tissue following the outline of the exterior $(s c l$.$) . Its attribution rests upon the general appearance of its$ tissues, bounded at the exterior by an epidermis which closely resembles the 'blow-off' layer as seen in certain of the sections. Its prominent wings, to the number of seven, corresponding to seven vascular bundles (v.b.), might well have been the base of such a seed as R. I10, which, as we have already pointed out, varied in this respect from the normal number of ribs, the hard tissue being perhaps the basal limit of the testa. The chief difficulties in the way of its acceptance are $(a)$ the rapidity with which the bundles are passing out, and $(b)$ the presence in the wings of secretory passages $(s . p$.$) , one in each. In any case it seems possible that the bundles$ of Conostoma remained distinct for some distance below the seed-base,

1 Oliver and Scott: On Lagenostoma Lomaxii. Phil. Trans., B, vol. 197, p. 206. 
perhaps to converge suddenly later to a single strand. Another section (R. I I $5^{-2}$ ) which gives food for speculation passes tangentially through the stalk. This shows what may have been a cupule containing a vascular strand. A peculiar feature of this preparation is that the plane of section should theoretically (if the seed be borne vertically on a straight stalk) pass through the axis of the stalk, but actually it cuts the stalk or cupule, as the case may be, tangentially and passes out on the same side ; therefore either the stalk in this instance was bent or else the seeds in this species were borne in a cupule in a similar manner to the closely allied seed Gnetopsis elliptica, where the insertion of the seeds and cupule is oblique to the main axis. ${ }^{1}$ The continuity is not convincing, but the fact that the possible cupule contains secretory canals suggests that the section R. I 3 may have been cut through the stalk at the base of the cupule, which would account for both the difficulties of its acceptance. In any case we ourselves regard the present evidence as quite inadequate for a definite decision.

\section{The Nucellus.}

This, the central body of the seed, requires detailed description in view of the unusual and possibly significant elaboration of structure shown by its distal portion which was concerned in the reception and storage of the pollen.

The nucellus falls into three regions:-

(I) The lagenostome, a structure evidently corresponding with the pollen-chamber of such a seed as Lagenostoma Lomaxii. It lies in a saucerlike depression at the summit of (2) the plinth, which forms the truncated continuation of $(3)$ the main body of the nucellus or megaspore chamber.

The lagenostome and plinth, though closely invested by the integumental lining ('micropylar funnel' and 'plinth jacket'), were free from the integument; the megaspore chamber, which extends from the chalaza to the level at which the apical tapering of the seed begins, shows on the other hand complete coalescence with the testa.

The horizontal septum separating the plinth cavity from the megaspore chamber is formed by the tapetum, and may for convenience of reference be termed the tapetal septum (cf. Text-fig. 3).

\section{The Lagenostome and Plinth.}

These two organs were so intimately related that it will be convenient to deal with them in the same section. The plinth is the tapering free end of the nucellus, on the flattened end of which the small urceolate lagenostome was inserted in a shallow, saucer-like depression. Apart from the remains of its internal filling tissue, to which reference will shortly be made, the plinth is as a rule in our specimens represented by its epidermis-

1 Renault : Cours de Bot. foss., vol. iv, Pl. XX, Fig. I. 
a mere shell-usually completely carbonized and appearing as a continuous black, structureless crust (cf. specimen R. I23, Pl. II, Fig. I9). Occasionally, the individual cells of which this shell was composed are preserved (specimen R. II4, Pl. I, Fig. 2, pl.), showing it to have consisted of a single layer of flattened epidermal cells destitute of special sculpturing.

Tracing this layer down the steep slope of the plinth to the level at which the tissues of nucellus and integument became confluent (R. I IO, P1. II, Fig. I4), it is found to curve sharply outwards and upwards (below s.), returning on its course as the lining layer of the integument which fitted the plinth like a jacket (cf. p. I4).

Followed in the other direction the epidermis of the plinth dips slightly at the summit to form the depression in which the lagenostome was lodged. It does not, however, reach the central part of this recess, which, as sections across this region clearly prove, was perforated (specimen R. I I 7, Pl. II, Fig. 16). The epidermis of the plinth at the insertion of the lagenostome curves abruptly upwards and outwards, and at the same time, changing completely its histological character, becomes evaginated to form the sculptured wall of the lagenostome (Pl. II, Fig. 18). Thus we see that the epidermal layer of the interior of the seed is in complete continuity throughout and that the
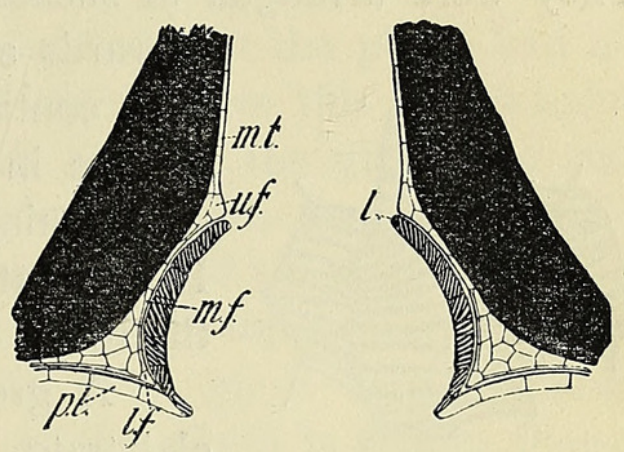

TeXT-FIG. 5. Conostoma oblongum. Diagram of median vertical section of lagenostome to show how it was enclosed by the micropylar tube and funnel. m.t., micropylar tube ; m.f., micropylar funnel; p.l., wall of plinth; u.f. and l.f., upper and lower flanges holding lagenostome $(l)$ in place. various regions termed the micropylar tube, micropylar funnel, plinth jacket, plinth and lagenostome walls, are merely different specialized portions of one and the same layer.

The lagenostome was a tiny goblet-shaped body, the cavity of which communicated with the plinth cavity. In shape it was slightly pyriform, its greatest horizontal diameter being about one-third up from its insertion. The mouth, which is rarely if ever shown in the sections, communicated directly with the micropylar tube, with which it closely engaged by a bevelled flange from the latter (Text-fig. 5, and Pl. II, Fig. I8). Unlike Physostoma and Lagenostoma, the mouth was unprovided with any tube or beak. In the former the mouth was placed on a low papilla (Text-fig. I2, p. 39), whilst in the latter the tapering tube of the pollen-chamber reached the surface of the seed (Text-fig. 12).

The principal dimensions of the lagenostome of Conostoma oblongum were as follows:-greatest horizontal diameter, $0.23 \mathrm{~mm}$. ; diameter at mouth, $0.12 \mathrm{~mm}$.; height, $0.15 \mathrm{~mm}$.

In Physostoma the lagenostome or pollen-chamber was I $\mathrm{mm}$. high 
$\times \mathrm{I} \cdot 2 \mathrm{~mm}$. wide; in Lagenostoma Lomaxii the corresponding dimensions were $0.75 \mathrm{~mm} . \times 0.7 \mathrm{~mm}$.

The cells which formed the wall of the lagenostome were in lateral continuity by about a third of the depth of their radial walls, thus leaving their major exterior portions free. It is due to this peculiarity, together with the obliquity of the sections, that the misleading appearance of a twolayered wall is due. This feature, strikingly shown by the preparations R. IIO (Pl. II, Fig. I4, lg.) and R. II 7 (Fig. I 8, lg.), might readily give rise to the view that the lagenostome was a two-layered structure. The radial dimension of these cells ranges from $26 \mu$ to $30 \mu$; the tangential horizontal is approximately $26 \mu$, and the tangential vertical $39 \mu$.

In form, the cells are roughly hexagonal as seen in tangential view. They were arranged in successive tiers with their shorter sides directed

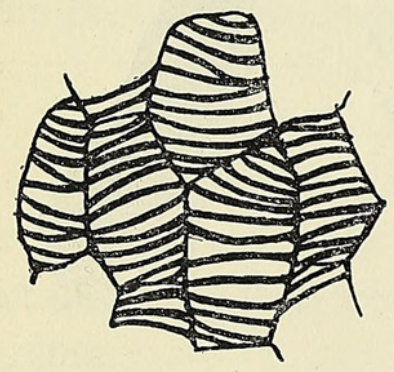

TEXT-FIG. 6. Sketch slightly diagrammatic, showing the sculpturing on the cells of the lagenostome. upwards and downwards. The wall seems to have been continued right up to the mouth without marked change in character, unless perhaps the appearance of thinning shown by preparation $\mathrm{R}$. II7 (Pl. II, Fig. 18) at the top of the lagenostome be not merely the result of post-mortem shrinkage.

A great feature of the cells of this layer was the elaborate, tracheid-like sculpturing of their wallswell shown in specimen R. II5, I (Pl. II, Fig. 20, lg.), and, on a much enlarged scale, in the adjacent textfigure (Text-fig. 6). These sculpturings, which were of the scalariform or slightly reticulated type, reach a maximum development on the tangential wall, i.e. the wall in contact with the integument. Other characteristic sections of the lagenostome are shown by specimens R. III, R. II4, and R. II6 (PI. I, Figs. 7, 2, and 6). These figures also illustrate the marked tendency. of this cell layer to undergo degeneration prior to fossilization. Thus in preparation R. II I (Pl. I, Fig. 7, lg.) the outer walls of one layer and the inner walls of the adjacent layer have perished, whilst in R. II6 (Fig. 6, lg.) solution has proceeded still further, so that little remains beyond the common radial walls of the obliquely cut cells.

Though these tracheid-like elements of the lagenostome were of delicate construction, they must, in virtue of their sculptured walls, have had a marked capacity to resist crushing forces. Occasionally the lagenostome is slightly retracted from the micropyle in consequence no doubt of post-mortem shrinkage (e.g. Fig. 7), but in all cases that have come under observation the form of the lagenostome is perfectly preserved.

The floor of the lagenostome did not consist of differentiated, sculptured cells, but was occupied by a pad of soft tissue which readily underwent displacement, leaving a clear orifice-well shown in preparations R. I I 7 
and R. II6 (PI. II, Fig. I8, and P1. I, Fig. 6). The plug which formed the floor is only slightly displaced in R. I 16 (Fig. 6, ls.), whilst in R. I IO (P1. II, Fig. I4, $l s$.) the cushion of soft tissue which hangs suspended from the lower rim of the lagenostome appears to be still in position.

The central cone of soft tissue that projected into the cavity of the pollen-chamber of Lagenostoma Lomaxii (Text-fig. 12, p. 39) does not appear to be represented in any of our specimens of Conostoma, though from analogy with that seed we regard it as certain to have been present in early developmental stages. Its absence from our specimens is best to be explained as a consequence either of very early deliquescence in development or imperfect preservation.

Before turning to the plinth cavity and its contents it will be convenient to mention a general character of this organ.

In occasional specimens of Conostoma we find that the plinth had not reached its full height, and as a rule lack of extension in this region seems to be correlated with other features which support the view that such specimens belonged to a younger stage of development than that usually found. Thus, in R.114 (Fig. 2), where, having regard to plane of section, the plinth is only half the usual height, the testa is immature and shows progressive sclerization. Again, in R. I22 (Fig. 3), a very immature specimen as judged by the testa, no trace of the plinth is visible, though were the specimen a normal one this region should fall within the plane of section. In view of these data and of the well-ascertained fact that the plinth is undeveloped in the small-sized seeds of Lagenostoma Lomaxii, ${ }^{1}$ there is good reason for supposing the plinth to have arisen as an intercalation at a relatively late stage in development. This extension of the nucellus just below the lagenostome must of course have been accompanied by a corresponding elongation of the free part of the testa, for, as we have seen, the relations between plinth and integumental lining were of the closest.

The cavity of the plinth now claims attention. It was a hemispherical chamber of variable height, as we have seen, extending from the tapetal septum, which formed its floor, up to the lagenostome. Its maximum height all over was $0.5 \mathrm{~mm}$. ; centre of floor to base of lagenostome, $0.3 \mathrm{~mm}$. Its contents, which only partly filled it, included (I) remnants of the soft interior tissues of the plinth, (2) pollen-grains. So far as information is afforded by our preparations, pollen when present in the seed was invariably contained in the plinth cavity, not in the lagenostome.

The soft interior tissue of the plinth is mainly preserved in the form of a horizontal, circular cushion which in section has the form of a concavoconvex lens, the convex side being uppermost. This cushion or lens, which

1 Oliver and Scott: On Lagenostoma Lomaxii. Phil. Trans., B, vol. cxcvii, p. 2 12, P1. IV, Figs. $I$ and 2. 
was preserved in the form of a delicate tissue, is not as a rule high enough to fill the space between the tapetal septum below and the base of the lagenostome above.

As regards the position occupied by the lens we find two extreme states. (a) In some cases the lens is found attached by its convex upper surface to the under side of the saucer in which the lagenostome rested (specimen R. I I0, Pl. II, Fig. I4, ls.), whilst its periphery hangs down into the plinth cavity -its edge being continued as a mere membrane which, often interrupted, can be traced obliquely downwards in the direction of the angle between the floor and sides of the plinth cavity, where it loses itself in the other tissues of the nucellus. Sometimes this membrane runs into the plinth wall just above the angle, sometimes it descends more steeply and strikes the floor just within the edge.

In addition to the lens, traces of plinth tissue are also found resting on the centre of the floor vertically below the lagenostome in the form of a hemispherical pad (R. I IO, Pl. II, Fig. I4, pd., and R. I I I, Pl. I, Fig. Io, pd.), the constituent cells of which usually show very poor preservation. The relation of this pad to the lens above suggests that it has been derived and separated from the middle concave part of the lens as a result of an increase in the height of the plinth cavity, with which extension the tissue which doubtless originally filled it has not kept pace (Text-fig. 7, C).

(b) An example of the other extreme state is afforded by specimen R. I 17 (Pl. II, Fig. I6), in which the whole of the plinth tissue (pl.t.) is found resting on the level floor of the plinth cavity. In this preparation what appear to be the same two portions of tissue are recognizable, viz. the lens tissue (pl.t., Fig. I5) with good preservation of its cells, and the central projecting boss or pad $(p d$.$) around which the former has collapsed.$

These two states are connected by intermediate conditions. Whilst in state $(a)$ the convex summit of the lens is in position and still adheres to the base of the lagenostome, specimen R. III (Pl. I, Fig. 7, ls.) shows some slight separation which is a good deal more evident in specimen R. I16 (Pl. I, Fig. 6, ls.).

In addition to these cases, which include the majority of specimens, there are still others in which the parts seem to approximate to their original positions (R. II9 and I23, Pl. I, Fig. II, and Pl. II, Fig. I9). It should be mentioned perhaps that in these two specimens evident traces of a prothallus are present in the megaspore chamber (Figs. II and I9, pr.), so that it may be conjectured that the stages in question are relatively old ones, whilst the presence of a pollen-grain in the closed plinth cavity of R. 123 (Fig. 19, p.g.) is a remarkable fact which requires explanation.

With a view to elucidating the significance of the various states of tissue distribution in the plinth cavity we shall now consider whether and 
how far it is possible to reconcile them with the probable course of events in the history of ovular maturation.

At an earlier stage of development than any represented by our preparations, the tip of the nucellus must have been occupied by a soft internal tissue which filled both lagenostome and plinth, the tissue in question being continuous from the one to the other through the narrow orifice by which these structures communicated (Text-fig. 7, A). As the time of pollination drew near the tissue of the lagenostome doubtless underwent solution through the agency of appropriate enzymes spontaneously secreted. At this time the floor or septum which lay between the plinth and the megaspore cavity must have been arched right up so that it was separated from the base of the lagenostome by the thickness of the lens-shaped cushion of tissue which we find surviving in later stages. Peripherally this tissue must have extended considerably further than does its surviving remnant in any of our specimens, and in particular it must have occupied the curving sides or 'shoulders' of the plinth. Text-fig. 7, A, may perhaps serve as a reconstruction of this early stage.

As the solution of the core of the lagenostome advanced the enzyme-action would traverse the base and involve the tissues of the plinth (Text-fig. 7, B).
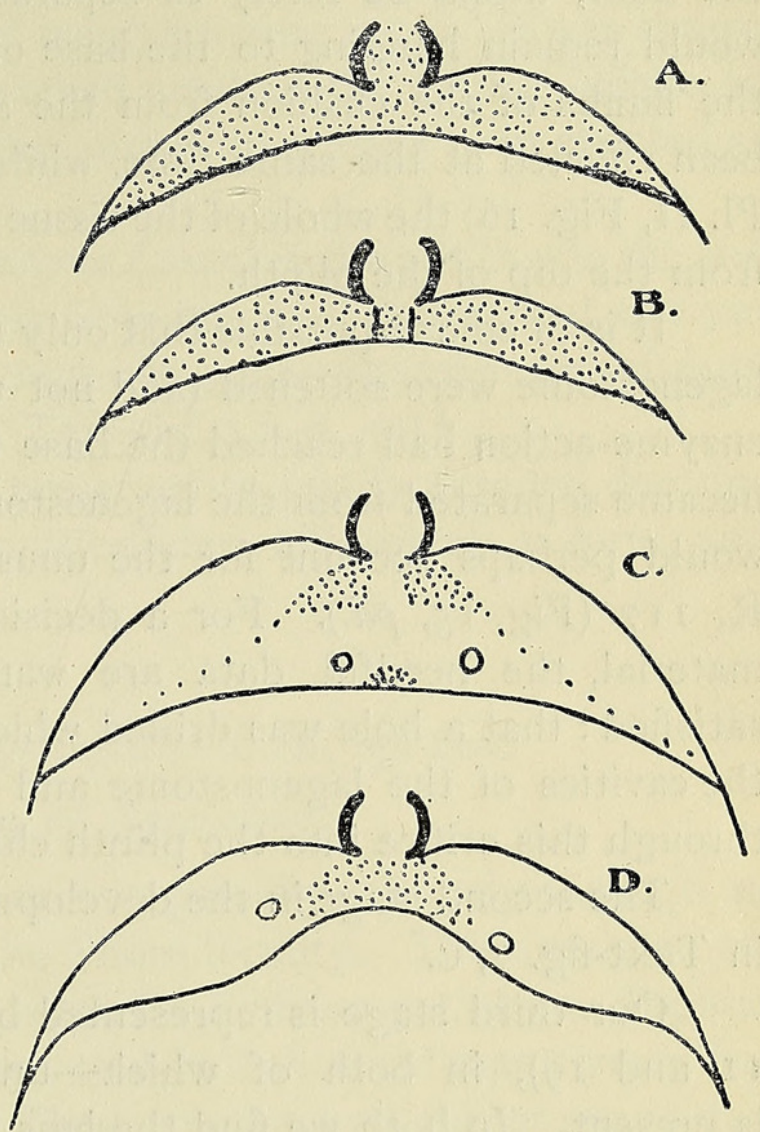

TEXT-FIG. 7. Diagrams of series of developmental stages (in part hypothetical) of plinth and lagenostome in a Conostoma, showing arrangements for entry of pollen into the plinth chamber. The dotted areas represent soft filling tissue. A, young stage; $\mathrm{B}$, cavity of lagenostome cleared of tissue and central patch of plinth tissue ready to separate as the plinth elongates (C); in $\mathrm{D}$ the prothallus has encroached on the plinth by means of a 'tent-pole' extension. Pollen present in $\mathrm{C}$ and $\mathrm{D}$.

To account for the next stage one of two assumptions has to be made: either the tapetal membrane (floor of plinth) tended to contract, or elseand we think this the more probable-the summit of the nucellus (including the lagenostome) continued to rise in consequence of a late extension localized in the plinth, whilst the tapetal septum remained stationary or at any rate lagged behind in its growth. Only in one of these two ways does it seem possible to explain the separation of the small central pad which rests on the tapetal septum from the lens suspended above (Textfig. 7, c). 
The state of tension in the plinth tissue, depicted above, would become effective as the enzyme-action, which had already dissolved the core of the lagenostome, advanced basipetally and involved the tissues of the plinth. For the effect of the enzyme would be to soften the central tissue of the cushion or lens (Text-fig. 7 B), thus removing serious resistance to the vertical extension of the plinth cavity. In this way a central pad, adhering to the floor, would be likely to separate from the cushion, which in its turn would remain hanging to the base of the lagenostome. The separation of the flanks of the cushion from the shoulders of the plinth may well have been effected at the same time, whilst in occasional examples (like R. II7, Pl. II, Fig. I6) the whole of the tissue of the cushion may have been liberated from the top of the plinth.

It is of course possible that only the peripheral layers of the core of the lagenostome were softened (and not the whole dissolved), so that when the enzyme-action had reached the base the whole of the central mass of tissue became separated from the lagenostome to form the pad on the floor. This would perhaps account for the unusually large dimensions of the pad in R. II7 (Fig. I5, pd.). For a decision on this point, which is not very material, the needful data are wanting. As to this, however, we are satisfied : that a hole was drilled which established communication between the cavities of the lagenostome and plinth, and that the pollen descended through this orifice into the plinth chamber.

The second stage in the development of the mechanism is reconstructed in Text-fig. 7 , C.

Our third stage is represented by specimens R. II9 and R. I23 (Figs. II and I9), in both of which-unlike any of the others-a prothallus is present. In both we find the lens in contact with the lagenostome above, whilst its lower surface rests on the arched floor. Moreover, in R. I 23 a pollen-grain is present in the plinth cavity, whilst one of the bodies in a similar position in R. II 9 may possibly be of the same nature, though the preservation is not good enough to say definitely. The problem we are trying to solve is the presence of the grain in this position with the other parts apparently blocking the way (Fig. I9).

Our conclusion as to the course of the pollen has already been stated; it made its way through a temporary orifice.

As the seed continued its development the prothallus made its appearance and a 'tent-pole' prothallial apex pressed on the septum from below, restoring the relations as we see them in specimen $R$. I23 (Fig. 19). The presence of a 'tent-pole' is indicated in both specimens-especially striking is it in R. II9 (Fig. II, t.p.), where the somewhat oblique plane of section has cut the prothallus twice, once at the projecting shoulder and again at the tip. Williamson's figure ${ }^{1}$ appears to represent a seed in the same phase as 
these two specimens, but we cannot speak critically as the preparation has not passed through our hands.

It still remains to be shown that warrant exists for the assumption that the wall of the plinth underwent a long-continued or intercalary extension which would provide the necessary machinery for 'uncorking' the basal orifice of the lagenostome, and thus letting the pollen through. We have already had occasion to comment on the structure of specimen R. II 4 (p. I2), which has all the appearance of being a young seed. It was shown that in this case the plinth had only reached one-half the normal height, so that evidently the main extension of this organ must have been effected at a late period in development.

Again, in the related seed Lagenostoma Lomaxii, the plinth was the last part of the seed to develop, as we know from the fact that it had not yet appeared in the small-sized seeds, although the pollen-chamber was already of full size and properly developed (cf. Text-fig. 1 2, p. 39). ${ }^{1}$

The pollen is not sufficiently well preserved to justify detailed description; suffice it to say that it was multicellular, ellipsoidal in form, and measured $75 \mu \times 65 \mu$.

\section{CONOSTOMA ANGLO-GERMANICUM, sp. nov.}

\section{Enumeration of Specimens.}

In the spring of 1904 an isolated section passing obliquely through an eight-ribbed seed was obtained from the Shore locality. This specimen remained of doubtful affinity until I909, when Dr. Kidston put at our disposal a series of four transverse sections from a coal-ball obtained many years before at Langendreer in Westphalia. These emphasized the previous suspicions that the seed was nearly allied to Conostoma oblongum. The close relationship was put beyond doubt when, owing to the generosity of Dr. Jongmans, who placed his slides and uncut coal-balls at our disposal, details of the internal structure were obtained.

Owing to the general character of its external form and the almost identical internal structure, we have no hesitation in provisionally referring this seed to the genus Conostoma $;^{2}$ altogether some twenty sections of this fructification are now available, of which the greater number are from the German material of Dr. Jongmans. Having regard to this double source of origin of our sections we propose the specific name of anglo-germanicum. Up to the present time four sections of this seed have occurred from English material, of which one is the oblique sectionalready referred to and the other three are more or less imperfect transverse sections, though of value as supplying our only information as to the histological structure of the testa.

In the following list the sections are enumerated, with their source of

1 Oliver and Scott : loc. cit。, p. 212, and P1. IV, Fig. I.

2 See footnote, p. 38 . 
origin and approximate plane. Those marked with an asterisk are figured in the plates.

\begin{tabular}{|c|c|}
\hline U.C.L., R. I $40 a^{*}, b^{*}, c, d^{*}$ & Series of four transverse sections \\
\hline J. $3^{*}$ & Oblique through pollen-chamber \\
\hline J. 4 & Tangential \\
\hline J. 5 & Oblique transverse \\
\hline J. $6^{*}$ & Oblique longitudinal \\
\hline J. $9^{*}$ & Oblique through pollen-chamber \\
\hline J. 10 & Tangential \\
\hline J. II & Oblique through middle \\
\hline J. $12^{*}$ & Longitudinal, passing through micropyle \\
\hline J. I3 & Oblique transverse \\
\hline J. I4 & Tangential \\
\hline J. 15 & Oblique transverse \\
\hline J. 16 & Oblique transverse \\
\hline U.C.L., Q. I * $^{*}$ & Oblique transverse near base \\
\hline U.C.L., R. I4I & Very imperfect transverse \\
\hline .C.L., R. I $42 a$ and $b$ & Imperfect transverse \\
\hline
\end{tabular}

Langendreer, Westphalia
Rheinpreussen (nr. Duisburg
",
",
",
",
",
",
",
",
Shore, Littleborough, I904
Dulesgate
Shore, Littleborough, I910

The specimens marked ' J.' are in the collection of Dr. J. W. Jongmans of Leiden. (The numbers of these specimens are provisional.)

The approximate plane of all the more important sections has been plotted on the longitudinal and transverse diagrams in Text-fig. 8.

\section{General Features.}

In the fundamental characters both of external form and internal organization the present species agrees closely with Conostoma oblongum. Like that species it was a straight, angled seed, roughly bullet-shaped, with a tapering apex and gradual insertion.

Internally there was an extensive plinth which had a comparatively small globular lagenostome at its apex. But whilst in essentials it was an undoubted Conostoma it possessed a very characteristic individuality of its own.

Superficially, the most striking feature was its extreme length as compared with its width ; this latter was the same as in the other species, but it attained a maximum length of $7 \mathrm{~mm}$. The main body of the seed was eight-angled, the angles bearing externally ribs which were alternately large and small ; the former in the middle region being twice as prominent as the latter (0.I I mm. and $0.05 \mathrm{~mm}$.).

The base of the seed tapered gradually to a thick stalk bearing eight wings, the lower extensions of the ribs. At the summit the surface curved inwards almost abruptly, terminating in a short conical apex pierced by the micropyle (Text-fig. 9). At the base of this tube the smaller ribs die out, but the four larger persist as wing-like expansions around the micropylar region, beyond the orifice of which outer margins are produced as free points. At the apex of the seed was an almost hemispherical depression about $0.4 \mathrm{~mm}$. deep, bounded by the internal edges of the wings (Text 
Affinities of the Palaeozoic Seeds of the Conostoma Group. 25

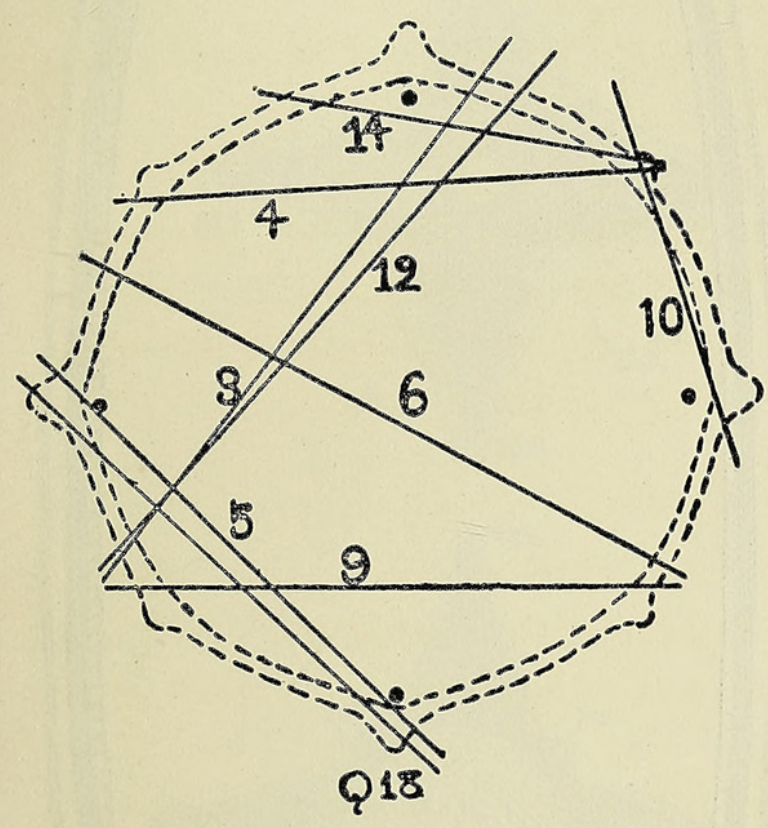

TEXT-FIG. 8. Conostoma anglo-germanicum. Plottings of the plane of section of all the more important preparations in respect to the vertical and horizontal planes. $\mathrm{R}$ and $\mathrm{Q}$. = Univ. Coll. Collection. J. $=$ Dr. Jongmans' Collection. The horizontal plane is at the height $a-b$ on the righthand figure.

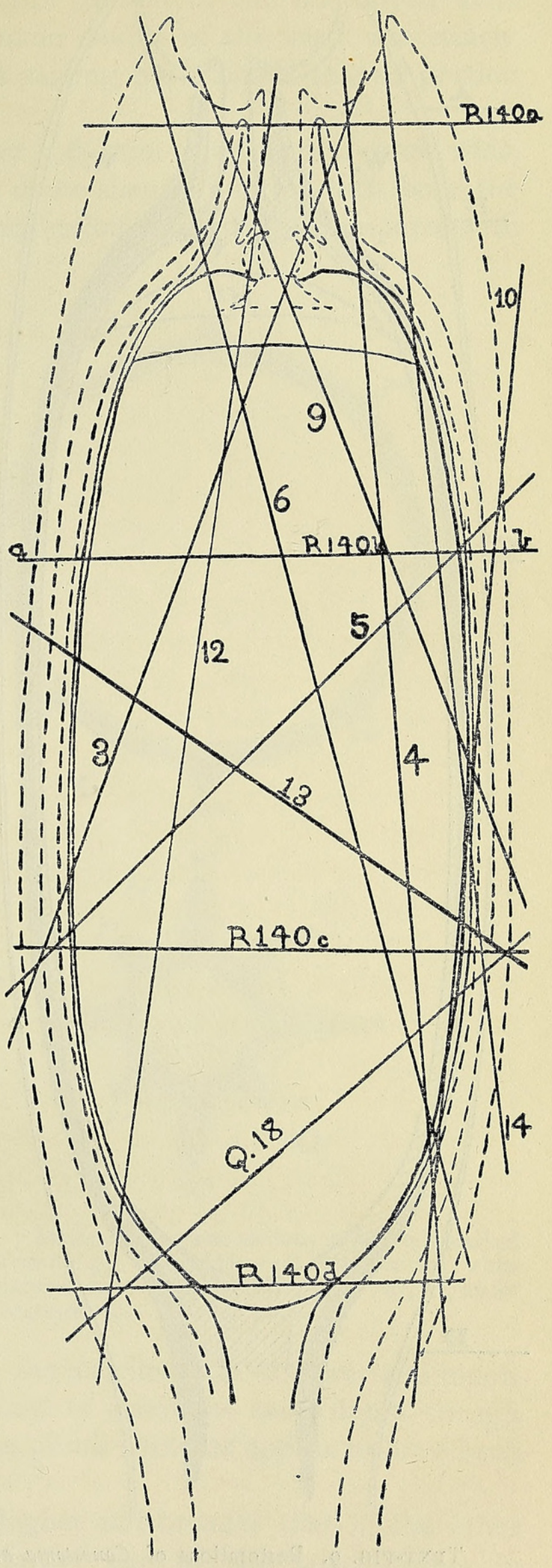



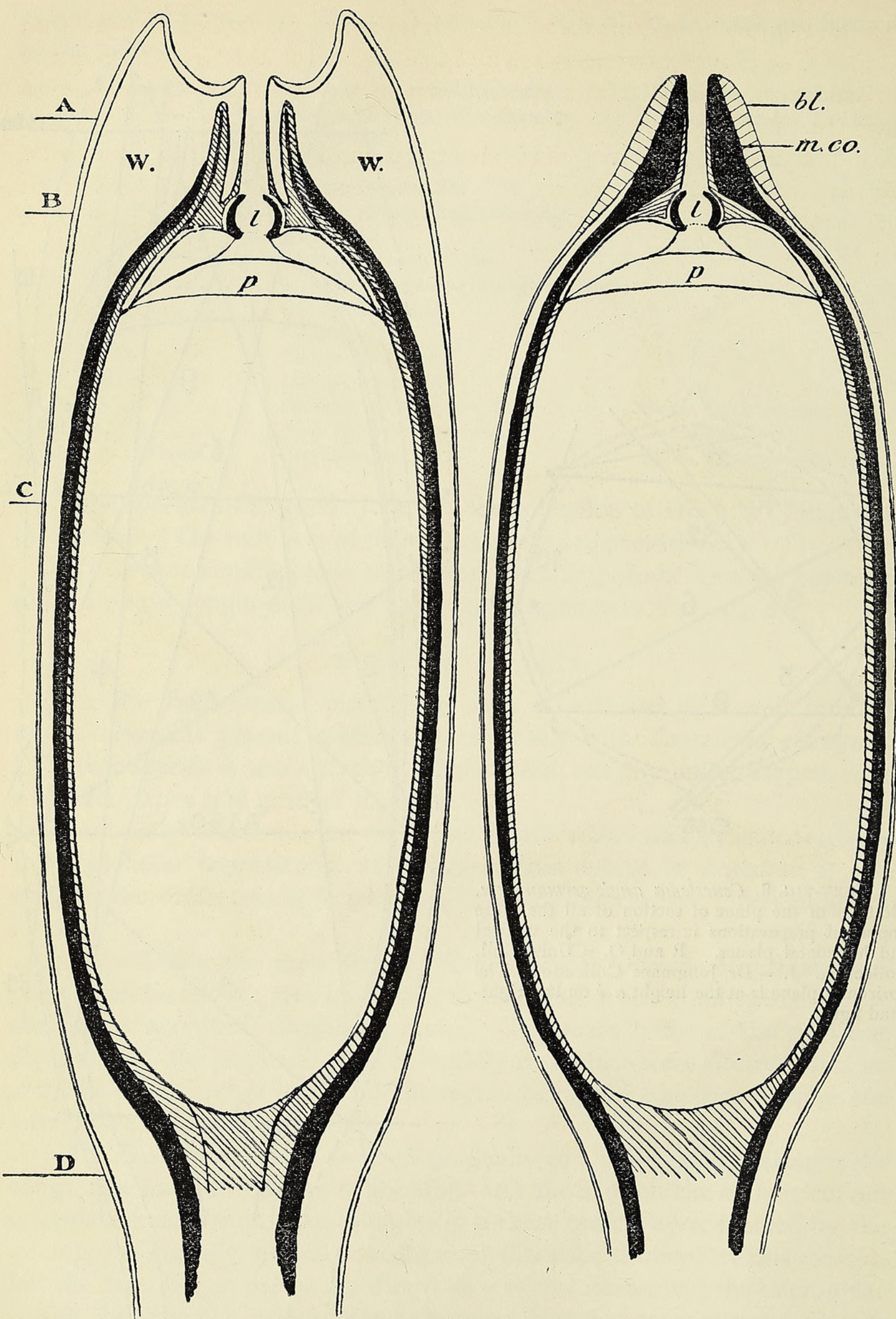

TEXT-FIG. 9. Restorations of Conostoma anglo-germanicum passing longitudinally through an opposing pair of major and minor ribs, respectively. The vascular bundle and nucellar wall are represented by a single line. The hard testa and lagenostome are in black, ribs and 'blow-off' white, and parenchymatous tissue shaded. bl., 'blow-off'; m.co., micropylar cone; l., lagenostome; $p$., plinth; w, w., wings formed by major ribs. $x$ about 25 . 
fig. 9 , w.), and into this depression the summit of the micropylar cone slightly projected (0.01 $\mathrm{mm}$.). The main cavity of the seed was nearly cylindrical, rounded at either end, and passing by a funnel-shaped portion into the tubular micropyle above.

The megaspore cavity was about $4.6 \mathrm{~mm}$. long and $2 \mathrm{~mm}$. wide, surmounted, as in $C$. oblongum, by a dome-shaped plinth which bore the characteristic lagenostome in a slight depression at its apex. Compared with

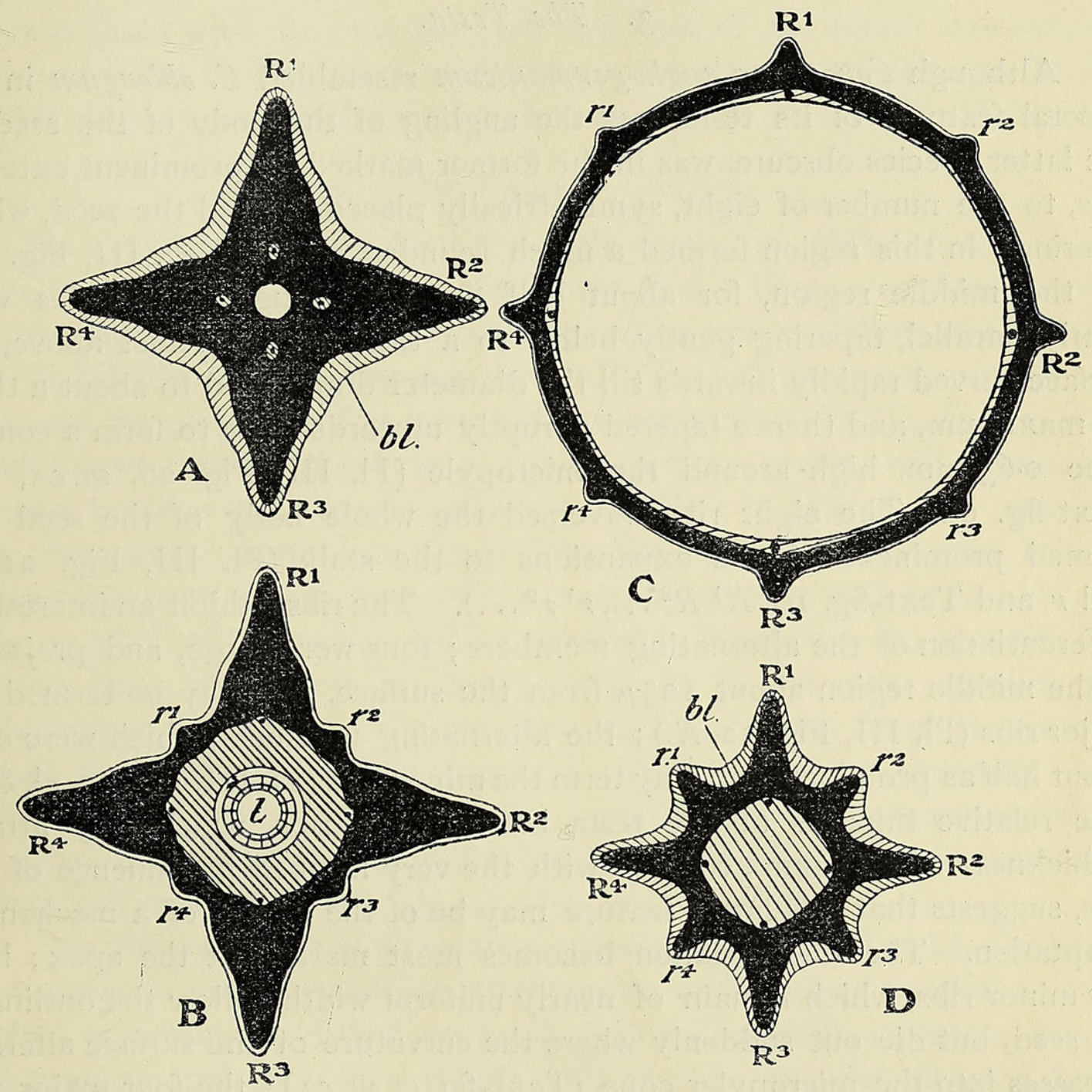

TEXT-FIG. Io. Conostoma anglo-germanicume. Series of transverse sections at the levels marked $A, B, C$, and $D$ in the vertical reconstructions (Text-fig. 9). The 'blow-off' layer is left white except in $\mathrm{A}$ and $\mathrm{D}$. The testa is black and the parenchymatous tissue shaded. $R^{1}, R^{2}, R^{3}, R^{4}$, major ribs; $r^{1}, r^{2}, r^{3}, r^{4}$, minor ribs ; $b l_{0}$, 'blow-off'; $l_{0}$, lagenostome. $x$ about 25 .

the internal structure of $C$. oblongum, the nucellus was narrower and much longer, whilst the plinth cavity remained of about the same depth, though slightly less extensive in width. The plinth contents appear to have been as in Conostoma oblongum.

The lagenostome was slightly higher and broader than in the other species, perhaps referable to the larger size of the pollen-grains in Conostoma anglo-germanicum. From the base of the plinth downwards, the 
nucellus and integument were joined, and between these two ran the four vascular strands which corresponded in position to the larger ribs.

The lobes of the canopy internally have almost entirely disappeared, and only four tapering loculi remain, no doubt filled with soft tissue into which the vascular strands passed. The general appearance of the seed may be gathered from Text-figs. 9 and 10, which give restorations in longitudinal and transverse section respectively.

\section{The Testa.}

Although Conostoma anglo-germanicum resembled $C$. oblongum in the general features of its testa, yet the angling of the body of the seed, in the latter species obscure, was in the former marked by prominent external ribs, to the number of eight, symmetrically placed around the seed, which interiorly in this region formed a much rounded octagon (Pl. III, Fig. 22). In the middle region, for about half the total length, the sides were nearly parallel, tapering gently below to a thick stalk; whilst above, the surface curved rapidly inwards till the diameter diminished to about a third its maximum, and thence tapered abruptly upwards so as to form a conical tube $0.65 \mathrm{~mm}$. high around the micropyle (Pl. III, Fig. 26, m.co., and Text-fig. 9). The eight ribs traversed the whole body of the seed and formed prominent winged expansions to the stalk (Pl. III, Fig. 2I, $R$ and $r$, and Text-fig. 10, $R^{1} R^{2} \ldots, r^{1} r^{2} \ldots$ ). The ribs exhibit an interesting differentiation of the alternating members; four were large, and projected in the middle region about $125 \mu$ from the surface, and may be termed the major ribs (P1. IIJ, Fig. 22, $R$.) ; the alternating members, which were only about half as prominent, we may term the minor ribs (Pl. III, Fig. 22, $r^{1}$, \&c.). The relative thinness of the testa between the ribs, which only attains a thickness of $0.1 \mathrm{Imm}$., coupled with the very marked prominence of the ribs, suggests that this latter feature may be of the nature of a mechanical adaptation. The differentiation becomes most marked at the apex; here the minor ribs, which remain of nearly uniform width, follow the outline of the seed, but die out suddenly where the curvature of the surface alters as it passes into the micropylar cone (Text-fig. $9, m . c o$.); the four major ribs continue their former gentle curvature above the shoulders of the seed, so that around the micropylar cone they become extensive wing-like expansions. A section cut at this level has the form of a four-rayed star, with the centre occupied by the micropyle (P1. III, Fig. 23). Beyond the orifice of the latter the free pointed ends of the ribs projected, and their internal margins bounded the cup-like hollow in which the micropyle stood (P1. III, Fig. 24, $R^{1} . e$. and $R^{3} . e$ ).

A median longitudinal section passing through two opposed major ribs appears concavely mucronate (Pl. III, Fig. 26), and somewhat resembles a similar section through the apex of Stephanospermum, where perhaps the 
cup-like expansion might be regarded as a lateral fusion of a number of such major ribs, of which, however, the individuality has been completely lost. ${ }^{1}$

In detail the hard testa was, as in C.oblongum, composed of two kinds of elements, viz. an external palisade and an internal fibrous layer; these together attained a width in the middle region of about $0.1 \mathrm{I} \mathrm{mm}$. (palisade $75 \mu$ and fibrous $3^{8} \mu$ ).

The inner soft portion of the integument is, as in the other species, only represented by a micropylar membrane continuous with the plinth jacket, and was fused with the nucellus from the base of the plinth downwards; the sinus between the plinth and integument is very clearly seen in J. 3 (P1. III, Fig. 29, s.), which forms a close parallel to R. I IO (Pl. II, Fig. I4).

\section{The Vascular System.}

The vascular supply further emphasized the differentiation which existed between the major and the minor ribs. There were four vascular strands, and these occupied the internal angles corresponding to the major ribs (PI. III, Fig. 27, v.b.)-were embedded in the soft tissue between the hard testa and the nucellus. The lowest transverse section (Pl. III, Fig. 2I, v.b.), which passes through the base of the megaspore cavity, still shows four vascular bundles cut across nearly transversely; so that if they united it was presumably some way down into the stalk. Above, the bundles entered the testa at the base of the micropylar cone and passed into the tapering loculi of the canopy, which reached to just below the apex (PI. III, Fig. 29, loc.); these were no doubt filled, as in the other species, with parenchymatous tissue. We see then that the testa here has reached a much more advanced stage than in $C$. oblongum; the progressive fusion of the unit portions of the canopy has gone further, and, corresponding to the disappearance of the alternate bundles, their loculi have become completely obliterated (P1. III, Fig. 23 , also Text-fig. 10).

This differentiation of alternate members in a whorl, of which Conostoma anglo-germanicum is so striking an example, finds a close parallel amongst modern plants in the ribbed seeds of certain Umbelliferae, where, too, we find primary and secondary ridges with vascular bundles situated below alternate members.

There is no evidence for the existence of any soft apical tissue in this seed, but the 'blow-off' layer.which extended over the whole seed attained very considerable dimensions between the major ribs at the apex (Pl. III, Figs. 23 and 29, bl.); and radial sections through the minor ribs show the cells of this layer with a dimension of as much as $0.19 \mathrm{~mm}$.; it attained, however, its greatest development between the wings at the base (Pl. III, Fig. 2I, bl.), thus contrasting with the other species in which this layer found its minimal development in this region.

1 F. W. Oliver: On Stephanospermum. Trans. Linn. Soc., and ser., Botany, vol. vi, Pl. XLIV. 
The fact that the 'blow-off', in all the sections where preserved, is still in situ, seems to point to its either having functioned differently or to the specimens in each case being immature; the presence of pollen in at least one of these preparations seems to render the former alternative the more probable.

Owing to the greater complexity of its outline, especially at the apex, this seed presents very varied appearances when cut in different planes of obliquity; this point is sufficiently well illustrated by specimen J. 6 (Pl. III, Fig. 3I), which cuts the seed obliquely, entering near the apex of a major rib and passing out at the base above the insertion of the stalk. The major rib on the left $\left(R^{1}\right)$ and the minor rib on the right at the apex $\left(r^{2}\right)$ are both exaggerated by the obliquity; but owing to the curvature of the proximal end of the seed this does not apply to the corresponding ribs at the base, which are cut nearly transversely. The upper lateral ribs $\left(r^{1}, R^{2}\right)$ are followed for some way, and consequently appear as obtuse angled appendages of the testa, whilst the lower lateral ribs $\left(r^{3}, r^{4}\right)$ are rendered cuspidate. The major ribs are respectively $R^{1}, R^{2}, R^{3}, R^{4}$, and the minor ribs $r^{1}, r^{2}, r^{3}, r^{4}$.

\section{The Nucellus.}

The structure of the nucellus of Conostoma anglo-germanicum closely resembled that of Conostoma oblongum in all essential points. The dimensions of the various parts differed as between the two seeds, the most notable divergence being in the height of the nucellus, which reached to $5 \mathrm{~mm}$., as compared with $3.7 \mathrm{~mm}$. in Conostoma oblongum. As in that seed, the lagenostome rests in a depression of the plinth (specimens $\mathrm{J} .3$ and 9, P1. III, Figs. 28 and $30, \lg$.), whilst the plinth itself is characterized by the same peculiar features that have been so fully described in the case of Conostoma oblongum. As we find the preservation of Conostoma anglogermanicum to be generally inferior to that of Conostoma oblongum, we shall restrict our detailed account of the former to the material points.

\section{The Lagenostome.}

The lagenostome resembled that of Conostoma oblongum in form, though its dimensions are slightly larger. Its height is $0.19 \mathrm{~mm}$., and the breadth $0.26 \mathrm{~mm}$., as compared with $0.15 \mathrm{~mm} . \times 0.23 \mathrm{~mm}$. in the allied seed. The cells of the wall appear somewhat more robust than in $C$. oblongum and, as in that seed, the cavity of the lagenostome is destitute of contents. Here also the appearance of a two-layered wall is suggested locally as in specimen J. 9, on the right-hand side low down (P1. III, Fig. $25, \lg$.) ; the explanation is doubtless the same as in C.oblongum (see p. 18) and depends upon the sectioning of a curved surface combined with post-mortem change. The 
state of preservation is as a rule inadequate to show the nature of the cellwalls; however, as at least one cell of the lagenostome bears distinct traces of sculpturing, it may be regarded as probable that in this respect also our seed was in agreement with Conostoma oblongum.

\section{The Plinth.}

The wall of the plinth survived as a carbonized crust, much as we find it in the poorer specimens of Conostoma oblongum. At its summit a similar depression was present, corresponding with the insertion of the lagenostome (Figs. 25, 29, and 30). The close relations already noted in the case of Conostoma oblongum between the plinth and lagenostome on the one hand, and the plinth jacket and micropylar funnel on the other, repeat themselves here in all essentials, even including the well-marked sinus just above the region at which nucellus and integument were confluent (cf. Pl. II, Fig. 14, and Pl. III, Fig. 29, s.).

The contents of the plinth are represented by the same structures as in Conostoma oblongum. From the base of the lagenostome the 'lens' hung suspended (Pl. III, Fig. 29, ls.), and below it in the same figure is found the pad of tissue which adhered to the tapetal septum ( $p d$.$) . In specimen$ J. 9 the 'lens' is slightly displaced, but its primitive position is still indicated by a connecting shred of membrane (Fig. 25, ls.). Pollen-grains are present in the plinth cavity of specimens J. 9 and J. 12 (Figs. 25 and 24, p.g.). Their average dimensions are $85 \mu \times 75 \mu$-somewhat in excess of those for the companion species.

Very distinct traces of a tapetum enclosing the megaspore chamber are present (Fig. 3I), but the character of the preservation hardly warrants detailed description. At the micropylar end the tapetum stretches across the nucellus as a septum, delimiting the base of the plinth (Fig. $3^{\circ}$ ).

\section{Comparison with Related Types.}

\section{Comparison with Gnetopsis elliptica.}

This famous seed was described and illustrated with some fullness by Renault in 1884 from specimens discovered in one of the Grand'Croix nodules. ${ }^{1}$ Apart from the supposed relations with the Gnetales, Gnetopsis remained for many years a very isolated type until the reinvestigation of Lagenostoma revealed the existence of certain features which these two seeds appeared to have possessed in common. ${ }^{2}$

With Conostoma oblongum the points of agreement are numerous and striking, and demand some notice here.

1 Renault : Cours de Bot. fossile, vol. iv, p. I80, Pl. XX, XXI, XXII.

2 Oliver and Scott : On Lagenostoma Lomaxii. Phil. Trans. B., vol. cxcvii, p. 233. 
The lagenostome of Gnetopsis has essentially the same form and insertion as in Conostoma. It is a small goblet-shaped body resting in a depression of the plinth with which its cavity became continuous. ${ }^{1}$ The cells of its wall constitute only a single layer, so far as we can judge from the specimens, but they show evident traces of sculpturing like that of Conostoma, though less well preserved.

Our examination of Renault's original type specimens shows that the presence of papillae around the mouth of the pollen-chamber in the preparations B. $23 \circ$, C. 2 and II ('languettes disposées en couronne') is to be interpreted as the result of partial resolution of the wall cells of the lagenostome by means of fissures corresponding in position with some of the vertical lines which, as in Conostoma, separated the adjacent rows of sculptured cells. The resulting lobes or finger-like packets, which included as a rule two or three vertical series of these cells, remained attached below to the summit of the plinth. ${ }^{2}$

The dimensions of the lagenostome in the three seeds are as follows :-

$\begin{array}{lccc} & \text { Gnetopsis. } & \text { C. oblongum. } & \text { C. anglo-germanicum. } \\ \text { Maximum width } & 2 \text { Io } \mu & 230 \mu & 260 \mu \\ \text { Width of basal orifice } & \text { II } 5 \mu & 180 \mu & 190 \mu \\ \text { Height } & \text { I } 45 \mu & 150 \mu & 190 \mu\end{array}$

The agreement with Conostoma is complete when the nature of the lobing in Gnetopsis is apprehended.

The Plinth. The broad low cavity between the prothallial chamber and the lagenostome corresponds with the plinth of Conostoma. It was naturally termed the 'pollen-chamber' by Renault as it is here that the pollen is usually found. ${ }^{3}$ The central portion of its cavity is occupied by a plug of tissue which rests on the floor, much as in our C. oblongum, specimen R. 1 I 7 (Pl. II, Fig. I6). Occasionally in Gnetopsis (B. 230, C. I2) this somewhat robust lump of tissue is produced towards the lagenostome into an upwardly directed, more delicate continuation. It is hardly possible to say whether the latter alone represents the displaced central core of the lagenostome whilst the lump below is the residual tissue of the plinth, or whether both may not have been derived from the lagenostomea difficulty also found in the interpretation of our R. II 7 (cf. p. 22).

1 Renault : loc. cit., PI. XXII, Fig. 4.

2 In Renault's preparations the lagenostome occurs under two types of preservation, i. e. the fingered or papillose type (which we interpret as macerated) represented in Cours de Bot. foss., vol. iv, Pl. XX, Fig. 3, and Pl. XXI, Fig. 3,e, and the intact type represented on his Pl. XXII, Fig. $4, t^{1}$. The information, for which we are indebted to Prof. Bertrand, that the intact type (which differs slightly in other respects) was probably derived from a source other than Grand'Croix (which provided the main series of specimens) explains the differences referred to.

${ }^{3}$ In all the specimens of seeds of the Conostoma group that have passed through our hands we have only detected a single pollen-grain in the lagenostome, viz. in Gnetopsis, the specimen being the one figured by Renault on his PI. XXI, Fig. 4 . 
The pollen-grains found in the plinth have $80 \mu \times 65 \mu$ as average dimensions, as compared with $75 \mu \times 65 \mu$ in $C$. oblongum, and $85 \mu \times 75 \mu$ in C. anglo-germanicum.

The Integument. The micropylar tube, funnel, and plinth jacket present in specimens B. 230, C. 2 and $6,{ }^{1}$ were doubtless integumental in origin. The tube reached a considerable length and was named the 'entonnoir' by Renault; in specimen B. 230 , C. $6,{ }^{2}$ it contained grains of pollen fossilized ein route to the lagenostome and plinth cavity.

A conspicuous feature of the integument, especially towards the apex of the seed, was the presence of 'un tissu lacuneux formé de grandes cellules disposées en lames parallèles'. 3 This tissue, conjectured by Renault to function as a float giving buoyancy to the seeds in water, resembles in the closest way the 'blow-off' tissue found in Conostoma, and we see no reason to doubt their essential identity. ${ }^{4}$

A great peculiarity of the seeds of Gnetopsis was the tuft of apical plumes inserted around the micropyle. Of these structures no trace is shown by Conostoma, so that unless they were caducous in the latter, their absence must be regarded as an important point of distinction between the two seeds. In view of the slight flattening detected in the body of Conostoma oblongum it is of interest to note that in Gnetopsis the symmetry was likewise modified in the direction of platyspermy $;^{5}$ whilst in C. oblongum, however, the whole of the six vascular bundles are accounted for, in Gnetopsis there are only four, those corresponding with the positions we suppose to represent the two major angles being absent. Gnetopsis thus appears to combine in itself the peculiarities of both our seeds, in showing the flattening of $C$. oblongum, with the disappearance of some of the bundles as in C. anglo-germanicum.

Another point in which Gnetopsis perhaps differed from our seeds was in the relatively slight development of a 'tent-pole'. As practically every specimen of Gnetopsis contained a prothallus these seeds should be of the right age, as judged by Conostoma, to show the 'tent-pole' had it reached any degree of prominence.

Turning to the cupule which formed the common enclosure of from two to four seeds in Gnetopsis, we have, as yet, no parallel in Conostoma, where the seeds are only known as detached objects. ${ }^{6}$

Having regard then to the various points cited, viz. the lagenostome, plinth, micropyle and plinth jacket, 'blow-off,' symmetry and distribution of vascular strands, we think the case for the close association of Gnetopsis with, or even its inclusion in, the Conostoma group a very strong one.

\footnotetext{
I Renault: loc. cit., P1. XX, Figs. 2, 3, 4.

3 Renault : loc. cit., P1. XX, Figs. 2 and $3, l$.

4 Cf. our Pl. III, Fig. 29, and Renault, loc. cit., P1. XXI, Fig. 3.

5 Cf. our Text-fig. I I, p. 34, and Renanlt, loc. cit., PJ. XXI, Fig. 6.

6 See however pp. 55 and 16.

2 Renault : loc. cit., Pl. XXI, Fig. 3, o.
} 
The only important point in which Gnetopsis differs from our seeds is in the presence of plumes at the apex, for which there exists no evidence in Conostoma; a minor point is the very slight development of a 'tentpole'. It is of course possible that even these points of difference may disappear as the seeds of the group become more fully understood.

Having regard to the occurrence of Gnetopsis, which reaches from the Middle Coal Measures up to the Stephanian at the top of the Carboniferous Formation, it is a matter of no little interest to find plants with the Conostoma type of seed mechanism

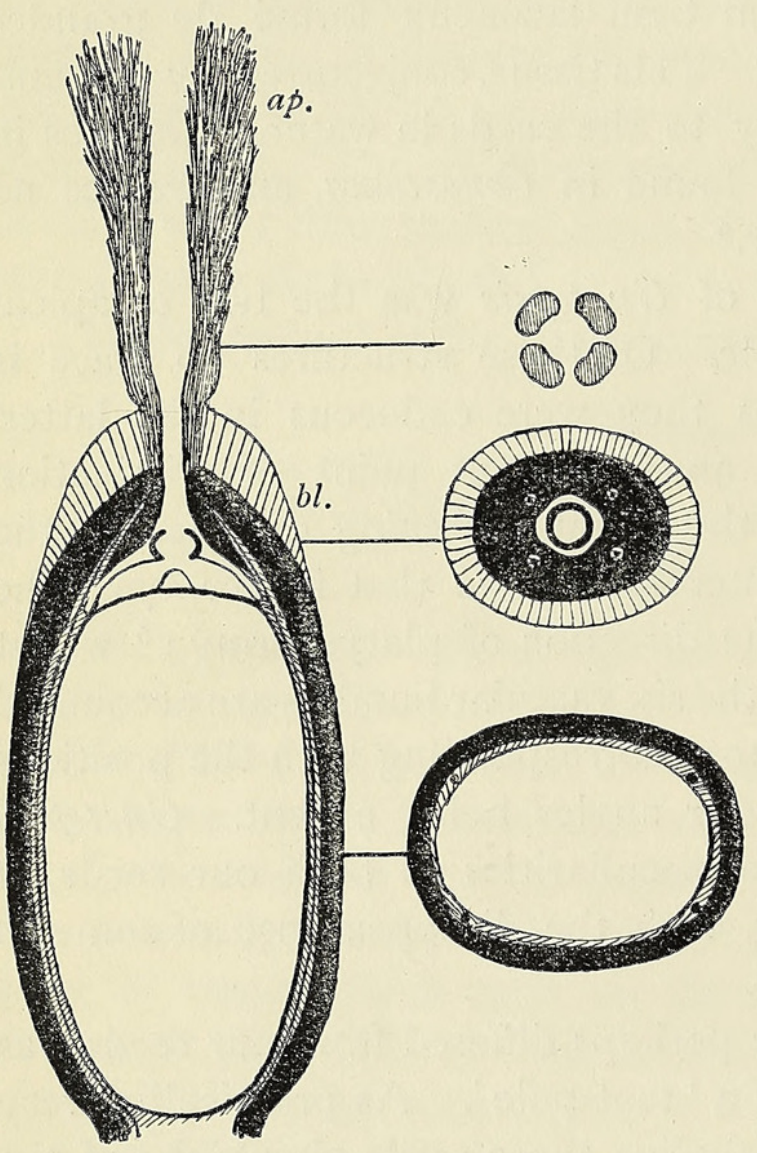

TEXT-FIG. II. Longitudinal and transverse restorations of Gnetopsis elliptica, largely hypothetical. $a p$., apical appendage. $b l .$, 'blow-off'.

persisting from the Lower Coal Measures right on to the close of the Carboniferous.

This long persistence points to the fact that the small lagenostome and large pollen-grain formed a combination at least as perfect as any other of the contemporary seminal arrangements of which we have any knowledge.

Before leaving the subject of Gnetopsis it seems worthy of remark that the cupule of that seed presents an interesting point of agreement with that of Lagenostoma Lomaxii. After comparing the specimens, we are much struck with the close resemblance in structure between the long tubular hairs with which the cupular lining of Gnetopsis was so abundantly provided and those met with in considerable quantity on the cupule of an ovular stage of Lagenostoma, and more sparingly on the old effete cupules. ${ }^{1}$

The occurrence of similar hairs in analogous positions on the cupules of the two seeds, though in itself a trivial point, gains in importance when taken in connexion with the other features of organization which these seeds had in common.

Until a detailed knowledge of the structure of the apical region of the testa in Gnetopsis is forthcoming, any close comparison between this region and the multilocular canopies of the other seeds is out of the question. The

1 Oliver and Scott : On Lagenostoma Lomaxii. Phil. Trans., B., vol. cxcvii, Pl. X, Fig. 34, h, and Pl. VIII, Fig. 8. 
presence, however, of a series of apical tufts at the micropyle is at least consistent with a lobed antecedent, and this equally whether these tufts consist of hairy prolongations of the actual ribs of the seed or whether, on the other hand, they are merely the expression of localized proliferations of the trichomes which may, however, have corresponded in position. In order to give precision to the remarks on Gnetopsis and to facilitate comparison with the other types, we have embodied our view of the structure of this seed in the convenient form of a text-figure (p. 34). The necessity for a detailed reconstruction happily does not arise, as we understand there is some prospect of Gnetopsis undergoing re-investigation at the hands of our friend Professor C. E. Bertrand, to whose good offices we are deeply beholden for the opportunity of consulting the specimens on the present occasion.

\section{Comparison with Physostoma.}

This seed belongs to an interesting generalized type in view of the prominence of the ribbing and the lobing of the testa. Moreover, the presence over the surface of the seed of large hairs probably containing mucilage affords a further variant of the mechanism which is illustrated by the 'blow-off' of Conostoma and the mucilage pegs of Lagenostoma.

The lagenostome of Physostoma with its all but sessile mouth forms a connecting link between those of Lagenostoma and Conostoma; the former with its tubular prolongation reaching to the surface of the seed, the latter with a true micropylar tube, integumental in origin, which fitted to the rim of the cup-like lagenostome with marvellous nicety.

Within the seed the 'tent-pole' prolongation of the megaspore chamber projected into the floor of the lagenostome, thus outstripping all other known cases. On the other hand the plinth is practically undeveloped. These facts of structure taken in connexion with the large number of ribs and lobes appear to be consistent with the view that Physostoma preserves several of the more archaic traits of the unknown precursors from which the various types may be supposed to have sprung. Among the features which on this view would belong to these precursors must be included the lobed, unfused micropyle, the many ribs, the mucilage epidermis, the terminal, indurated, capacious lagenostome, and the 'tent-pole'. The extension of the plinth, on the other hand, is to be regarded as a later intercalation.

\section{Comparison with Lagenostoma.}

The features which unite Lagenostoma and Physostoma are too well known to need recapitulation here. ${ }^{1}$ As compared with Conostoma the loculi of the canopy in Lagenostoma had a more extensive filling tissue and relatively thinner peripheral and radial layers of sclerized elements, the

\footnotetext{
1 Oliver: On Physostoma. Ann. of Bot., vol. xxiii, p. I08.
} 
filling tissue in the former being reduced to a mere parenchyma sheath accompanying the vascular strands into the loculi.

A peculiarity of Conostoma oblongum was the soft tissue at the apex of the integument, of which no indications have been detected in Lagenostoma.

In both genera the integumental units show a high degree of coalescence in the micropylar region, the degree of fusion being considerably greater however in Lagenostoma than Conostoma, which appears somewhat to approach the condition of Lagenostoma (Physostoma) Kidstonii, Arber. ${ }^{1}$ This coalescence of integumental units may be regarded as yet another example of a generally diffused tendency, no doubt correlated with a simplifying of the mechanism of development, viz. the replacement of separate parts borne at the same height by a continuous structure.

The lagenostome of Lagenostoma reaches the exterior of the seed by a tubular prolongation, thus contrasting markedly with the etubular condition of Conostoma, where a functional micropyle is provided on the lines of most existing Gymnosperms. In view of this difference, it is not possible to regard the two types of seed as very closely related.

Other contrasting features include the nature of the wall sculpturings of the lagenostome-which are not reticulate in Lagenostoma; its relatively large size and the persistence of a central core of tissue-not yet detected in Conostoma.

The plinth, which was present in full-sized seeds of Lagenostoma but not in the small ones (Text-fig. I2), sloped up at a very gentle angle as compared with the corresponding part of Conostoma ; its presence being correlated rather with a transverse than with a material longitudinal expansion of the nucellus. A 'tent-pole' does not appear to have been produced.

Thus it is plain that whilst both Conostoma and Lagenostoma have proceeded along similar lines in the coalescence of the integumental units, they show considerable divergence in the details of lagenostome structure, in the plinth, and in the arrangements for the reception of the pollen.

\section{Classification and Diagnoses.}

In the light of the previous discussion it is convenient to separate the various seeds that have been enumerated into three series or types, all of which possessed in common:-

(I) A nucellus and integument confluent up to the level of the plinth ; (2) a free part of the integument consisting either of separate lobes, or of a more or less completely fused series of lobes forming what has been termed a 'canopy'; (3) a vascular system of strands running in the deeper parts of the integument and passing into the lobes or their representatives at the apex; (4) an epidermis to the testa which was mucilaginous, at any rate

1 E. A. N. Arber: On some New Species of Lagenostoma. Proc. Roy. Soc., B., vol. lxxvi. 
locally; (5) a terminal, specialized, more or less pear-shaped receptacle for the pollen known as the lagenostome.

These three series of types, with provisional diagnoses, are as follows :--

\section{i. The Physostomeae.}

Free parts of the ribbed integument consisting of separate segments surrounding and overlapping the large, globose lagenostome which opened by a small orifice inserted on the apex of a low papilla. Plinth rudimentary. The apex of the megaspore cavity projected into the floor of the lagenostome. Ribbing at base obsolete.

Physostoma elegans, Will.

Physostoma Kidstonii, Arber.

\section{ii. The Conostomeae.}

Seeds ribbed or angled, tapering at apex: free part of integument consisting of more or less fused lobes. The lining of the integument formed the passage for the large pollen-grains and was thus a true functional micropyle leading down to the very small, included lagenostome, the wall of which consisted of cells with reticulated or scalariform sculpturings ; base of lagenostome communicating with the extensive plinth cavity into which the pollen-grains penetrated. Integument with a mucilaginous epidermis extensively developed at the apex.

\section{Conostoma, Williamson.}

Cylindrical or slightly flattened seeds with tapering insertion. Ribbed throughout, or at base with angles passing into ribs. Lobing at apex variable; vascular bundles equalling or fewer than the ribs or angles; loculi of canopy nearly obliterated and equalling the vascular bundles in number; epidermis mucilaginous.

Lagenostome very small, included; cells of wall sculptured.

Plinth conspicuous, dome shaped, with internal tissue; well-marked 'tent-pole' and tapetum present.

\section{Conostoma oblongum, Will.}

Organization of the Fossil Plants of the Coal Measures, Pt. viii. Phil Trans., 1877 , p. 243 , Figs. $80,80 *$ (Pl. XI), 80* (Pl. XII), 8I and 86.

Localities. Oldham; Dulesgate; Shore, Littleborough; Halifax; Deighton, Yorks.

Horizon. Lower Coal Measures.

Seed six-angled, winged at base only; six vascular strands; apex ending in six soft, free lobes.

Dimensions : length $6 \mathrm{~mm}$., broadest diameter $2.3 \mathrm{~mm}$. 
2. Conostoma anglo-germanicum, sp. nov. ${ }^{1}$

Localities. Shore, Littleborough; Dulesgate; Langendreer, Westphalia; Colliery Rheinpreussen, near Duisburg-Seam Finefrau, Nebenbank.

Horizon. Lower Coal Measures.

Seed eight-ribbed, the four major vascular more prominent than the four minor non-vascular, which fall short of apex.

Dimensions : length $7 \mathrm{~mm}$., broadest diameter $2.3 \mathrm{~mm}$.

Gnetopsis elliptica, Ren. and Zeill.

\section{iii. Lagenostomeae.}

Free part of integument consisting of more or less completely united segments ; very obscurely angled. Lagenostome with tube reaching surface of seed and persistent central cone of tissue; low plinth with gentle gradient; no 'tent-pole'.

Lagenostoma ovoides, Will.

Lagenostoma Lomaxii, Will. MS.

Lagenostoma Sinclairii, Arber, perhaps came here.

An outer envelope or lobed cupule has been described for L. Lomaxii and L. Sinclairii.

It is probable that Miss Benson's Sphaerostoma ovale (Will.) will have to be added as a fourth type to the three enumerated above. Its inclusion here would be premature as the seed is undergoing re-description.

With the exception of Lagenostoma Lomaxii, which has been definitely referred to Lyginodendron Oldhamium, the parentage of none of the seeds has been determined. In view, however, of the broad agreement in type which they all show, an ultimate reference of these seeds to plants of Lyginodendron affinity seems not improbable.

As a convenient collective name for the whole of the seed types or series just enumerated we would suggest, at any rate for provisional use, the name Lagenostomales.

\section{Vi. The Pollination Mechanisms of the Lagenostomales.}

The detailed study of the various seeds grouped under the Lagenostomales has led to the recognition of three distinct types of mechanism

1 The course followed here of including this seed as a second species of Conostoma perhaps demands a word of explanation. The peculiar character of the ribbing, with alternation of major and minor ribs, would go far to justify the creation of a new genus, particularly when regard is had to the relative importance of the testa as a diagnostic character in fossil seeds. Earlier workers in this field have repeatedly founded genera on equally trivial characters, e. g. Brongniart in his Graines silicifiées. Our motive in refraining for the present from raising C. anglo-germanicum to generic rank is to emphasize the fact of the essential identity of its internal organization with that of C. oblongum. 
concerned in the reception and storage of pollen. Briefly stated, these mechanisms were as follows :-

I. The unjoined but approximated lobes of the integument surrounded and overtopped a relatively large lagenostome which bore an orifice seated on a low central papilla. At the time of pollination it is probable that these lobes collectively formed a tube or funnel narrowing towards the mouth of the lagenostome. If so, this type possessed a functional micropyle which played its part in the passage of the pollen (Text-fig. I2, Physostoma). This type may be termed a fimbriated micropyle.

2. A relatively massive canopy of united segments was perforated by a long micropyle which led down to a small, included lagenostome, the
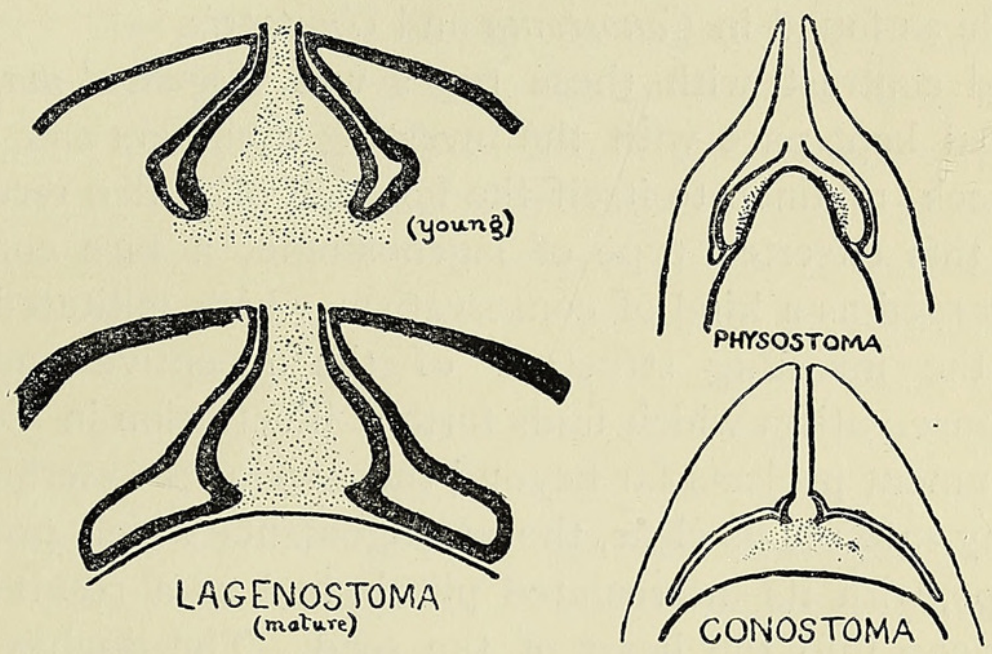

TEXT-FIG. 1 2. Diagrams to show the relations of lagenostome, plinth, and canopy in Lageno. stoma, Physostoma, and Conostoma. The regions where soft-filling tissue occurs are dotted, i.e. the central cone of the lagenostome in Lagenostoma, a shallow cushion resting on the flanks of the intrusive apex of the megaspore chamber in Physostoma, and a lens-shaped cushion below the lagenostome in Conostoma. Two stages of Lagenostoma are shown.

cavity of which became confluent with that of the plinth below by deliquescence of the filling tissues. The pollen-grains which traversed the micropyle and lagenostome were received into the plinth cavity, where they doubtless underwent maturation. This type is marked by a plinth of considerable vertical extension, an organ not conspicuously developed in type I (Text-fig. I2, Conostoma).

3. The lobes of the integument were fused into a compact canopy which closely invested the conical lagenostome, the orifice of which reached to the outer surface of the seed. In this type the lagenostome must have been directly pollinated without the intervention of the micropyle. A plinth was present, but had only a trifling vertical extension (Text-fig. I2, Lagenostoma).

So far as efficiency in the collection of pollen-grains was concerned, each type appears to have been perfectly satisfactory. The presence of much pollen in the lagenostome of Lagenostoma, and especially in the 
species L. ovoides, has already been a matter of comment, ${ }^{1}$ whilst in Physostoma no fewer than eighty grains have been counted in a single section that recently passed through our hands-a number that may safely be trebled to get an approximation to the full number. In Conostoma, with its long micropyle, tiny lagenostome, and plinth cavity, the evidence shows that an abundance of large pollen-grains found their way into the plinth cavity.

When regard is had to the relations of the parts in these three types, it seems evident that, assuming them to be derived from a common ancestral group, the reception of pollen was originally independent of the integument. If the free lobing of the integument of Physostoma is an archaic character, then in so far as these lobes collectively assisted at pollination this pristine method of pollen reception has been lost and an approach made to the entire micropyle as found in Conostoma and Gnetopsis.

In marked contrast with these types was Lagenostoma, where the lagenostome had kept pace with the investing members and, by means of its elongated neck, retained to itself the function of pollen reception. The persistence of this exserted type of lagenostome, a rare condition, may perhaps be regarded as a kind of conservatism which militated against the surrender to the investing structure of the receptive and conductive functions-a conservatism which finds further illustration in Gnetum, where the inner integument projects far beyond the envelopes exterior to itself.

This at any rate seems clear, the arrangements which prevailed in the Conostoma type, with its intercalated plinth, had as a result the carriage of the pollen deep into the heart of the seed. The double functions of reception and storage relinquished by the lagenostome were taken over by the micropyle and plinth cavity respectively, the lagenostome persisting as a sort of inner vestibule-a mere piece in an elaborate though doubtless very perfect mechanism. The very smallness of the lagenostome, whose diameter never exceeded I $50 \mu$ in the known representatives of this typea dimension barely equalling the length of two pollen-grains as we know them in the plinth cavitity - fully accords with this vestigial phase upon which the lagenostome would appear to have entered.

Passing on to the seeds of other groups, we come first to members of the Medulloseae, of which Trigonocarpus, Stephanospermum, and a number of the French Permo-carboniferous seeds afford the best known examples. In these, so far as information is available, there existed a prominent nucellar beak which engaged with the base of the micropyle. The pollen was received by this tubular beak from the micropyle and passed into a deeper lying 'pollen-chamber' below, perhaps comparable to the plinth cavity of Conostoma. The flattened seeds usually referred to the Cordaiteae appear to be in substantial agreement, whilst the same remark holds good of the living genera of Cycads and of Ginkgo.

1 Oliver and Scott: loc. cit., p. 214. 
In this connexion it is interesting to note that in Stangeria and Ginkgo, as figured respectively by Lang ${ }^{1}$ and Hirasé, ${ }^{2}$ the apical papilla of the nucellus which becomes perforated is limited by a prominent epidermis, as to which Lang remarks, "The superficial cells of the pointed tip seen in Fig. 12 have their walls thickened and form a very definite boundary to the sides of the chamber, suggesting a close comparison with the corresponding region of certain fossil gymnospermous seeds.' ${ }^{3}$ The actual place which the pollen reached-the 'pollen-chamber'-is found at a deeper level, a statement also holding good of the fossil seeds to which passing reference has been made. Thus, whilst the facts in so far as they are known are consistent with an elaboration of the nucellus, on lines analogous to Conostoma, in the seeds of the Medulloseae, Cordaiteae, recent Cycads, and Ginkgo, to say that the beak of the nucellus in these seeds corresponds with a vestigial lagenostome, and the pollen-chamber with a plinth cavity, would be premature if not erroneous. Much fuller details of ovular development than are yet available are required before we can advance further.

Before leaving this part of the subject reference may be made to the presence in several siphonogamous Gymnosperms of examples of ovules of which the nucellus undergoes spontaneous disintegration at the apex before the arrival of the pollen. Whilst this procedure would appear to be the rule in the three genera of Gnetales, in Ephedra ${ }^{4}$ and Gnetum ${ }^{5}$ it was carried so far that definite excavations or ' pollen-chambers' were produced. The functional significance of this peculiarity in plants whose fertilization is accomplished by the agency of pollen-tubes is far from evident, and we must await new light from current or future investigations. We would only remark in this connexion that the past history of the Gnetales and of such Conifers as show analogous arrangements ${ }^{6}$ may be the determining factor in the possession of a mechanism which has somewhat the appearance of being an anachronism.

\section{General Discussion on the Testa.}

The ribbing, which is so general a character of these and allied seeds, is broadly an indication of a multiple origin of their integuments. Whatever the nature of the members which coalesced to form this organ, it seems reasonable to assume that primitively each of the coalescing members had its own vascular strand, and that the correspondence which usually obtains, both in number and in position, between the ribs and bundles, is an expression of one and the same fact, viz. the multiple origin. In Physostoma

1 W. H. Lang : Ann. of Bot., vol. xiv, Pl. XVII, Fig. I5.

${ }^{2}$ S. Hirasé : Journ. Coll. Sci. Tokyo, vol. xii, Pl. IX, Figs. 31 and 32.

${ }^{3}$ Lang: loc. cit., p. 286.

- W. J. G. Land : Bot. Gaz., vol. xxxviii, Pl. V, Fig. 44.

${ }^{5}$ Lotsy : Ann. Jard. Bot. Buitenzorg, vol. xvi, P1. V, Fig. 35.

${ }^{6}$ e. g. Sciadopitys verticillata; see Lawson, Ann. of Bot., vol. xxiv, Pl. XXIX, Fig. ${ }^{3}$. 
the ribs passed out into free tentacles at the apex, each with its own vascular bundle, and in the young seed the conjunctive tissue between the ribs was
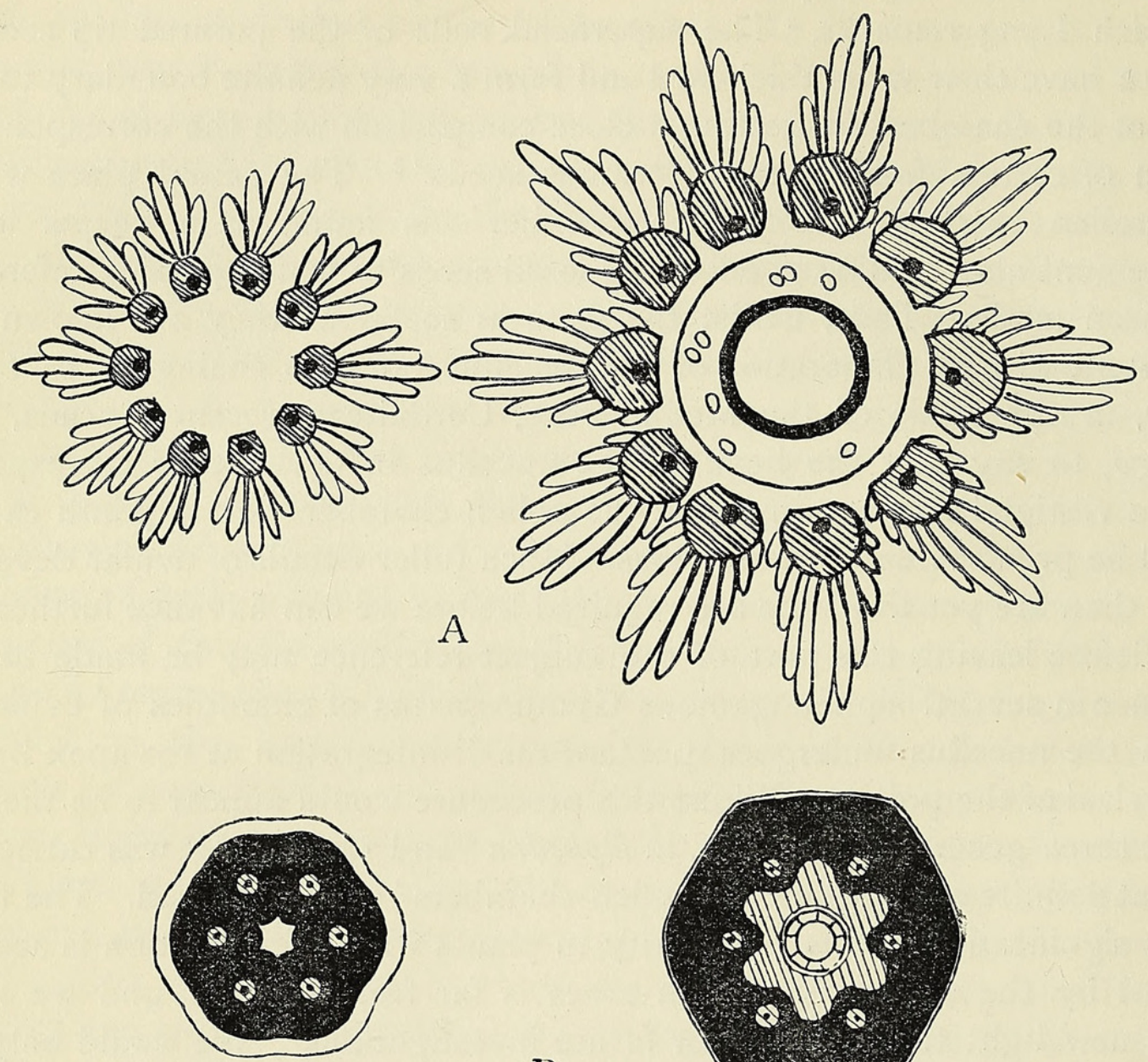

$\mathrm{B}$
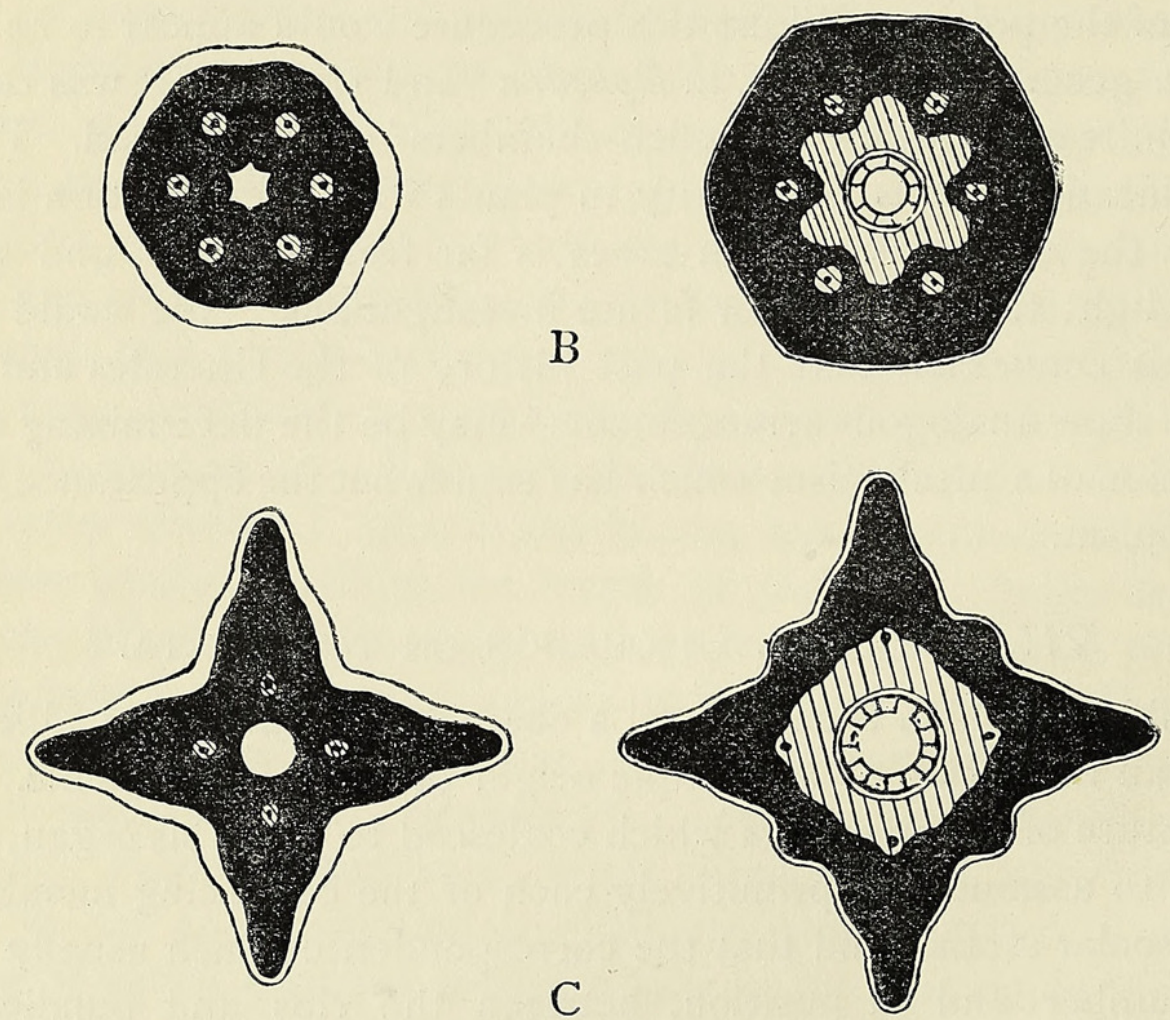

TeXT-FIG. I3. Transverse sections (diagrammatic) passing through the apex and the lagenostome of Physostoma (A), Conostoma oblongum (B), and Conostoma anglo-germanicum (C). Parenchyma shaded : testa in black : 'blow-off' white.

much less developed than in mature specimens, perhaps an ontogenetic recapitulation of phylogeny. ${ }^{1} \quad$ This is still further borne out by the gradual

1 Oliver : Ann. of Bot., vol. xxiii, p. I00, Pl. VII, Fig. 29. 
elimination of members as we pass from those seeds in which the lobes are partially free to those in which they are almost completely fused. In Physostoma, where the multiple integument is most marked, the number is ten ; in Lagenostoma Lomaxii, which has a slightly lobed apex, nine ; and in Conostoma oblongum, where the lobes are internally almost obliterated, six (Text-fig. I3).

The primitive condition of each member was, we think, that seen in Physostoma, where the tissue of each tentacle consists of undifferentiated parenchyma. As we pass along the series, we find progressive sclerization proceeding inwards from the whole periphery of each member, thus tending towards the final obliteration of the parenchyma which formed the 'loculi' of the canopy, the sclerization having its inception historically before the fusion of the constituent members. In this way the alternate loculi in Conostoma anglo-germanicum have disappeared, though still represented exteriorly by the minor ribs. This gradual decrease in the number of bundles may have culminated in their total suppression, resulting in a condition similar to that in the integument of present-day Phanerogams.

With the more complete fusion of the component members came a gradual loss of vascular tissue. This diminution of the vascular supply of the ovule was restrained in those forms where, as in Cycads, the motile sperms are still retained, but elsewhere, as in most Gymnosperms and the whole of the angiospermic series, where siphonogamy has replaced zoidiogamy, the vascular supply tends to become reduced to a mere basal cup with rare indication of its distal extensions. Thus this view, which has already been put forward, seems to find in these seeds two more links in the chain of evidence. ${ }^{1}$

It seems not improbable that, as already suggested, the prominent ribbing in C.anglo-germanicum has a definite mechanical value, for the seed is an exceptionally long one as compared with its width, whilst the testa between the ribs is even thinner than in the much shorter seed of C.oblongum. This suggestion seems to find corroboration in Polylophospermum, where, too, there is pronounced ribbing associated with a thin sclerotesta and great length. ${ }^{2}$ From the integumental standpoint we can then regard $C$. anglogermanicum as a late stage of the series, in which only four members remain as such, the peripheral portions of all the members still being retained as ribs in relation to their mechanical value; whilst Gnetopsis, with four ribs only, probably forms its culmination.

In the medullosean series of forms there is a similar relation existing between ribs and bundles. The latter are, however, situated within the sarcotesta and exteriorly to the ribs. In Trigonocarpus Parkinsonii, Br.,

1 Oliver: On the Ovules of the Older Gymnosperms. Ann. of Bot., vol. xvii, I903, p. 45 I.

2 Oliver: Notes on Trigonocarpus and Polylophospermum. New Phyt., vol. iii, No. 4, 1904, p. 96 . 
there are three principal ribs, three secondary, and six tertiary. The six bundles subtend the last.

In Polylophospermum stephanense, $\mathrm{Br}$, there are six major ribs and six minor, each with a bundle.

If the origin of the integument here was similarly multiple, we must assume that there was complete fusion of the individual members before the inception of sclerization. This latter extended along the inner surface of the fused organs. The ribs may have been purely mechanical and utilitarian in origin, and their relation to the bundles of a similar nature to that which is exemplified in the leaf of a Cordaitean such as $C$. angulostriatus, where sclerization has proceeded at both surfaces and produced prominent ribs at each bundle, and between each pair of bundles a secondary rib and two symmetrically placed tertiary ribs on either side. In modern Cycads, such as Macrozamia spiralis and Encephalartos Altensteinii, the bundles in the outer flesh overlie the ribs of the sclerotesta. ${ }^{1}$ If the integument here be double, as some hold, ${ }^{2}$ it could only be homologized on this view by the assumption that sclerization took place, in time, subsequent to the fusion of the outer and inner integuments.

A further point of general interest as regards the testa, and perhaps of some considerable significance, is the flattening observed in the seed of Conostoma oblongum; this platyspermy is even further developed in Gnetopsis elliptica, where it is associated with a reduction of the number of bundles to four (Text-fig. II). The appearance of the transverse section of the latter seed could be readily obtained from the former if we suppose the two major ribs to have lost their bundles and the corresponding angles to have been flattened to a gentle curve. These facts, taken together with the general tendency exhibited in the group towards the reduction in number of the vascular strands accompanied by a corresponding reduction in the number of ribs or angles, point to the possibility of this tendency having been carried still further, resulting in the production of a seed with only two vascular strands and a testa exhibiting a bilateral symmetry comparable to that of Cardiocarpus. But whether such a seed definitely referable to this chain of affinity be found or not, the facts seem to indicate that, whilst the terms 'radiospermic' and 'platyspermic' have a definite use as morphological distinctions, our attitude towards them as criteria of taxonomic importance may require readjustment.

The presence in Conostoma and Gnetopsis of the highly specialized layer we have termed the 'blow-off' seems to call for some explanation. Probably to be regarded as homologous with the peg-producing layer of Lagenostoma and the epidermis with its mucilage-containing hairs in Physostoma, its

1 M. C. Stopes: Beiträge zur Kenntnis der Fortpflanzungorgane ảer Cycadeen. Flora, I904,

2 Coulter and Chamberlain, p. I58, Morphology of Spermophytes, I90 I ; M. C. Stopes, loc. cit. 
secretory nature may be due to the same internal causes that have so frequently rendered vestigial structures secretory among living plants. The 'blow-off' layer and the soft apical tissue of Conostoma oblongum may be the remnant of a once much more extensive tissue comparable to the sarcotesta of the medullosean series. The closest analogy which modern plants offer appears to be the megaspore of Pilularia. Here the mucilaginous layer which invests the megaspore serves to attract and retain the sperms; above the archegonium the mucilage forms a deep funnel, which becomes filled with spermatozoids. ${ }^{1}$ In Conostoma the mucilage layer, as in Pilularia, reaches its maximum development at the apex. In Conostoma oblongum the epidermis split up the flanks of the free apical lobes, as is seen in Pl. I, fig. 6, $b l$.; the expanding mucilage must thus have found its way into the micropyle and in the space between the apical lobes. If the seeds were retained till after pollination this mucilage may well have acted as a drop mechanism comparable to that of the present-day Taxus. If, however, as might have been the case, the seeds were first shed, perhaps the mucilage played a part analogous to Pilularia in capturing and nourishing the male cells. Our knowledge, however, of the functions of mucilage, even in recent plants, is so incomplete as to render the problem in fossil plants extremely difficult.

In Conostoma anglo-germanicum and Gnetopsis the 'blow-off' is not exfoliated even in specimens showing pollen-grains. We probably have then in all these seeds to deal with a common physiological cause, and any value the layer may have had in certain cases is to be regarded as a secondary adaptation.

\section{Conclusion and Summary.}

The facts recorded in the foregoing paper go to prove that the seeds of the palaeozoic epoch showed, within certain well-defined limits, a considerable degree of diversity in mechanism.

When regard is had to the dominance which seed-possessing plants afterwards attained, it is hardly surprising that the seeds of Coal Measure times should have shown unmistakable indications of modification and elaboration in a variety of different directions.

This diversity, as it affected the apex of the seed, is fully illustrated in Text-figs. 12 and I3. Whilst the actual parts involved are in fundamental agreement-lagenostome, plinth, and a compound integument-the detailed relations of these parts are altogether different. In Physostoma the large lagenostome was enveloped in the lobes of the integument, which collectively formed what may well have been the precursor of the micropyle in this group of seeds. In Lagenostoma these arms were united into a chambered 'canopy', which whilst investing the lagenostome, was overtopped by the orifice of the latter, which thus had direct access to the sur- 
face of the seed. The other extreme is afforded by Conostoma, where the minute lagenostome lay at the foot of a long and specialized micropyle which traversed a canopy in which the unit parts, though more highly modified than in Lagenostoma, were still recognizable.

A peculiar organ, the plinth, claims special attention in Conostoma, not merely from its dimensions, but also on account of the part which it played in the reception of pollen. Though this zone or region is represented in all three types, it is only in Conostoma, and the probably related Gnetopsis, that it attained to any special significance. To what extent the nucellus of existing Gymnosperms-especially Cycads-may have undergone analogous elaboration cannot be stated with any confidence owing to the defective state of our knowledge of the developmental history of the ovules.

The ribbing and angling of these seeds also raises matters of interest dealt with in the body of the paper (p. 4I). In these ribs there appear to be presented traces of what may be regarded, in the light of Physostoma, as the original segments or lobes of the ancestral integument. As these show considerable variety, even in allied seeds, in the relative prominence and in the presence or absence of accompanying vascular strands, it is evident that no great reliance can be placed on these characters for diagnostic purposes - especially where the larger groups are concerned. Incidentally, it may also be remarked that incipient stages in the passage from radial to bilateral symmetry appear to be illustrated by both Conostoma oblongum and Gnetopsis elliptica. This shows, if further proof be needed, that the old provisional distinction of palaeozoic seeds into radiospermic and platyspermic types had little or no significance as a guide to affinity.

Though allusion has been made to the modification and elaboration in different directions which the seed underwent, it would be premature hastily to suppose that our different types had necessarily diverged from a common seed-possessing ancestor. In these days when the doctrine of polyphylesis is steadily gaining ground, the alternative view that (to take a concrete case) Physostoma, Lagenostoma, and Conostoma had been separately derived from as many related but distinct cryptogamic types will certainly have to be considered. On that view, then, the differences between our seeds would depend not only on such divergences as arose after the establishment of the seed habit, but they would be, in part at least, determined by inherited differences already present (or latent) in the several ancestors.

Moreover, the coming of the seed habit must, from the evolutionary point of view, have marked a relatively active period ; for, even if we suppose the qualifications for seed-bearing to have been acquired in cryptogamic days, there must have been a transitional period during which the less immediately serviceable portion of the cryptogamic inheritance was either eliminated or underwent functional change.

These considerations may perhaps serve to indicate some of the diffi- 
culties which beset the allocation to their exact place in phylogeny of the various structures and mechanisms which collectively constitute the seed.

In the foregoing paper, the subject-matter of which is set forth in the table of contents (p. I), we describe in detail two palaeozoic seeds, Conostoma oblongum, Will., and C. anglo-germanicum, sp. nov. ; these, with Gnetopsis, are provisionally placed in a separate group, the Conostomeae, ranking with the Physostomeae and Lagenostomeae as subdivisions of the larger class Lagenostomales. The seeds of the Conostoma type are compared with related forms, whilst diagnoses of the species and provisional diagnoses of the groups are given. In the more general parts of the paper especial attention is drawn to the arrangements for the reception and maturation of pollen found in the various seed types and to the peculiarities of the testa.

\author{
University College, LONDON, \\ November, 1910.
}

\title{
IX. Glossary of Terms employed.
}

'Blow-off.' An epidermal layer of presumed mucilage-containing cells, forming the outermost investment of the testa (p. I4).

Canopy. The apical portion of the hard testa consisting of a varying number of more or less fused members surrounding the free portion of the nucellus.

Cupule. A free sheathing structure arising from the peduncle and investing one or more seeds.

Doubly oblique or Assymetrically oblique. Applied to a section which is oblique both to any plane of symmetry and to the axis of the structure cut (p. I2).

Flange. A ring-like projection of the integumental lining of the micropyle (p. I4).

Lagenostome. A differentiated chamber at the apex of the nucellus formed by modification of the epidermis. The lagenostome is either included where the integumental micropyle forms an intermediate passage between its orifice and the exterior, as in Conostoma, or exserted where by upward extension of the lagenostome it communicated with the exterior direct, e. g. Lagenostoma.

Lens. The contracted tissue of the plinth which frequently remained attached to the base of the lagenostome (p. 20).

Loculus. A chamber present in the canopy usually represented by a space, but probably filled with parenchymatous tissue continuous with the soft part of the integument lining the seed cavity, and into which the vascular strand passed.

Major rib or angle. Applied to the large ribs or angles of a seed irrespective of their vascularity (p. 28).

Minor rib or angle. Applied to the lesser ribs or angles of a seed where these latter fall into two categories only; in other cases the terms secondary and tertiary are employed.

Micropyle. The passage to the nucellar apex formed by the integument, which may be of three kinds, viz. a fimbriated micropyle of non-fused members, as in Physostoma; an entire micropyle, as in Conostoma; or an investing micropyle, as in Lagenostoma.

Micropylar funnel. The lower portion of the micropylar tube where it expands to join the seed cavity (lagenostome jacket).

Micropylar tube. The passage formed by the micropyle.

Micropylar membrane. The integunental epidermis lining the micropyle-often found separated.

Oblique. Applied to a section of which the plane is at right angles to a plane of symmetry but oblique to the axis of the structure cut. 
Pad. The central portion of the lens (p. 20).

Plinth. The free portion of the nucellus supporting the lagenostome (p. i6).

Plinth jacket. The epidermis of the soft integument surrounding the plinth. the apex.

Shoulder. A term applied to that part of a structure where it begins to curve inwards towards

Sinus. The space between the free portion of the nucellus and the integumental lining or the gaps in a fimbriated micropyle.

Tapetal septum. The septum separating the megaspore cavity from the apex of the nucellus.

Tent pole.1 A raised central portion of the apex of the prothallus.

\section{Literature cited.}

Arber, E. A. N.: On Some New Species of Lagenostoma. Proc. Roy. Soc., B., vol. 76, 1905.

CAMPBell, D. H. : Mosses and Ferns. New York, 1905.

Coulter and Chamberlain: Morphology of Spermophytes. New York, Igor.

Hirasé, S. : Études sur la fécondation, etc., du Gínkgo biloba. Journ. Coll. Sci. Japan, vol. xii.

LAND, W. J. G.: On Ephedra. Bot. Gaz., vol. xxxviii.

LANG, W. H.: On the Gametophytes and Ovule of Stangeria. Ann. Bot., vol. xiv, 1900.

Lawson, A. A. : The Gametophytes and Embryo of Sciadopitys verticillata. Ann. Bot., vol. xxiv, I9IO.

Lotsy, J. P. : Contributions to the Life-history of Gnetum. Ann. Jard. Bot. Buitenzorg, vol. xvi.

Oliver, F. W.: On the Ovules of the Older Gymnosperms. Ann. Bot., vol. xvii, I903.

: On Stephanospermum. Trans. Linn. Soc., and ser., Bot., vol. vi, 1904.

: Notes on Trigonocarpus and Polylophospermum. New Phyt., vol. iii, I904.

: On Physostoma elegans. Ann. Bot., vol. xxiii, I909.

Oliver and ScotT: On Lagenostoma Lomaxii. Phil. Trans. B., vol. cxevii.

Renault, B. : Cours de Bot. fossile, vol. iv.

Salisbur y, E. J. : On the Extrafloral Nectaries of the Genus Polygonum. Ann. Bot., vol, xxiii, 1909.

ScotT, D. H. : Studies in Fossil Botany, 2nd Ed., I909.

Stopes, M. C. : Beiträge zur Kenntnis der Fortpllanzungsorgane der Cycadeen. Flora, 1904.

Williamson, W. C.: On the Organization of the Fossil Plants of the Coal Measures, Pt. viii. Phil. Trans., 1877 .

\section{EXPLANATION OF PLATES I-III.}

Illustrating Messrs. Oliver and Salisbury's paper on Conostoma group of Palaeozoic Seeds.

U. C. L., R., and Q. = University College London Collection.

$\mathrm{J}$. = Dr. Jongmans' Collection.

W. = Mr. D. M. S. Watson's Collection.

PLATE I.

FIGS. I-I I (Photographs).

Fig. I. Nearly longitudinal section through seed, showing the boat-shaped ontline. The cushion (ls.) is in position just beneath the lagenostome (lg.), and the micropylar membrane $(\mathrm{m} . \mathrm{m}$. has contracted from the hard testa $\left(t_{\text {. }}\right)$. U. C. L., R. III (Shore). $\times$ I2.(see p. I0).

1 S. Hirasé : Études sur la fécondation, etc., du Ginkgobiloba. Journ. Coll. Sci. Japan, vol. xii, p. II3. 


\section{Affinities of the Palaeozoic Seeds of the Conostoma Group.}

Fig. 2. Apex of young seed cut obliquely, showing the plinth jacket $(p l . j$.$) and wall of plinth$ $(p l$.$) in close contact. The cells of the testa \left(t_{0}\right)$ show contents, and the plinth tissue is slightly displaced from the base of the lagenostome (lg.). U. C. L., R. II4 (Halifax). $\times 80$ (see Pp. I2, I4).

Fig. 3. Apex of young seed cut tangentially. The 'blow-off' layer (bl.) is in position on the left, but on the right has exfoliated. The cells of the soft apical tissue (st.) are well shown and pass gradually into the hard tissue below $\left(t_{\text {. }}\right)$. U. C. L., R. 122 (Shore). $\times 70$ (see pp. I 2 and I5).

Fig. 4. Oblique section through winged base of seed, showing basal portions of the cell-walls of the 'blow-off' layer still attached $\left(b l . w_{0}\right)$ to the prominent wings of the base $\left(r^{4}, r^{5}, r^{6}\right)$. U.C. L., R. II0 (Dulesgate). $\times 36$ (see p. I5).

Fig. 5. Transverse section through middle region of seed. The somewhat flattened outline is well shown and the structure of the testa with outer palisade $(p a$.$) and inner fibrous layers (f b$.$) .$ $m a$. and mi., major and minor angles. U. C. L., R. II9 (Shore). $\times 26$ (see p. 10).

Fig. 6. Oblique section through apex, showing three lobes of 'blow-off' (bl.). The cells of the cushion (ls.) are well preserved. lg. lagenostome wall; $m . m$. , micropylar membrane ; pl., plinth. U. C. L., R. 116 (Shore). $\times$ 70 (see p. 18).

Fig. 7. Median longitudinal section through apex of same specimen as Fig. I, showing the micropylar membrane $(m . m$.$) cut obliquely and consisting above of superimposed tiers of cells.$ The lagenostome $(l g$.$) is cut tangentially. b l$. ., 'blow-off' layer; $l s$. , lens or residue of plinth tissue. U. C. L., R. II I (Shore). $\times$ I00 (see p. I4).

Fig. 8. Oblique section through micropyle, showing the soft tissue at the apex (s.t.) separating from the testa below $\left(t_{0}\right)$; the loculus of the canopy on the right (loc.) shows the vascular bundle (v.b.). $m . m$. , micropylar membrane. W. 267 (Shore). $\times 64$ (see p. 12).

Fig. 9. Transverse section of base of seed, showing seven wings. bl., 'blow-off'; scl., sclerenchymatous cells; v.b., vascular bundles; c.s., central space; $s . p$. , one of the secretory passages. U. C. L., R. II3 (Halifax). $\times 40$ (see p. I5).

Fig. Io. Somewhat oblique longitudinal section through seed passing out above the stalk; seven ribs are present $\left(\boldsymbol{r}^{1}, \boldsymbol{r}^{2}, \ldots\right)$, two of them with their vascular bundles preserved $\left(v \cdot 6 .{ }^{5}\right.$, v..$^{7}{ }^{7}$. s., sinus; lg., lagenostome; ls., lens; $p d$. ., pad. U. C. L., R. IIo (Dulesgate). $x$ I 8 (see p. I2).

Fig. II. Doubly oblique section through seed, showing contained prothallus ( $\left.p r_{\text {. }}\right)$ with 'tentpole' $(t . p \cdot)$; the shoulders of the plinth cavity (pl.c.) are exaggerated by the direction of the section. bl., 'blow-off'; $r^{\prime}$ and $r^{2}$, ribs asymmetrically cut. U. C. L., R. II9 (Shore). $\times 30$ (see p. I2).

\section{PLATE II.}

Figs. I 2-20 (Photographs).

Fig. I2. Oblique section of seed above the lagenostome, showing the soft apical tissue above (s.t.) and with 'blow-off' ( $b l$.) exterior to it. The micropyle is in the centre of the figure, its lining membrane $(m . m$.$) is seen as a fluted layer. At the top of the figure are two somewhat displaced$ lobes of the canopy $\left(l ., l_{\text {. }}\right)$ with a sinus (s.) between. W. 268 (Shore). $\times 70$ (see p. I 3).

Fig. I3. Portion of apex of seed given in PI. I, Fig. I, showing the outer edge of the testa 'blow-off' raised up by pegs of mucilage beneath (pe.); m.m., micropylar membrane. U. C. L., R. III (Shore). $\times$ I95 (see p. I5).

Fig. I4. Median longitudinal section through lagenostome, plinth, and adjacent parts. $l g$., lagenostome with apparently two wall layers; $p l$., wall of plinth; $b l . j$. , plinth jacket; s., foot of sinus between plinth and plinth jacket; $l s$., remains of plinth tissue ('lens') adhering to lagenostome; $p d$., pad resting on tapetum; v.b., position of vascular strand. U. C. L., R. IIo (Dulesgate). $\times 85$ (see p. 20).

Fig. I5. Central part of Fig. I6 enlarged. $p d$., central pad resting on remains of plinth tissue (pl.t.) ; p.g., pollen-grains, the upper right-hand one with internal cells. U. C. L., R. I I 7 (Shore) $\times 182$ (see p. 20).

Fig. I6. Longitudinal section of upper part of seed, showing testa $(t$.$) , and base of micropyle$ $(m c$.$) , lagenostome (l g$.$) , plinth \left(p l_{.}\right)$, and remains of tissue of plinth (pl.t.) resting on the tapetal septum $(t a p$.$) ; part of the tapetum has separated as a blister. Around the pad are several pollen-$ grains $(p . g$.$) . loc., loculus of canopy; s., base of sinus between plinth and plinth jacket. Photo-$ graphed by Mr. W. Tams. U. C. L., R. II (Shore). $\times 3^{8}$ (see p. 20). 
Fig. 17 . Longitudinal section of lower end of seed, showing testa ( $\left.t_{.}\right)$, and tapetum (tap.) several eell layers deep. U. C. L., R. I 21 (Shore). $\times 80$.

Fig. 18. Lagenostome enlarged from specimen given in Fig. I6. lg.o., outer layer of wall, lg.i., inner layer of wall of lagenostome; pl., wall of plinth ; $p l . j .$, plinth jacket ; $u . f$. , upper flange, l.f., lower flange of lagenostome. U. C. L., R. II7 (Shore). $\times$ I 25 (see p. 7).

Fig. 19. Median section of apex of seed with prothallus $(p r$.$) ; the asymmetry of the internal$ ribbing of micropyle wall shown. i.r., internal rib; m.t., micropylar tube; m.f., micropylar funnel ; $l g$. , lagenostome ; pl., plinth cavity ; $l .$, tissue of plinth ('lens'); p.g., pollen-grain; t.p., 'tent pole' ; tap., tapetum. U. C. L., R. 125 (Deighton, Yorks.). $\times 75$ (see p. 20).

Fig. 20. Longitudinal section of micropylar tube (m.t.) and lagenostome; the wall of the lagenostome is cut tangentially, the cells showing conspicuous reticulated sculpturing. U. C. L., R. II5, I (Shore). $\times 182$ (see p. 18).

\section{PLATE III.}

Fig. 2I. Transverse section through base of the megaspore cavity, showing the basal wings formed by the major ribs $\left(R^{1}, R^{2}, R^{3}, R^{4}\right)$, three of which have corresponding vascular bundles, and the minor ribs $\left(r^{1}, r^{2}, r^{3}, r^{4}\right)$, which have no vascular elements. tap., tapetum; bl., 'blow-off' layer. U. C. L., R. I $40 d$ (Langendreer). $\times 27$ (see p. 29).

Fig. 22. Transverse section from the same series as above through the middle region. Major ribs $\left(R^{1}, R^{2}, R^{3}, R^{4}\right)$; minor ribs $\left(r^{1}, r^{2}, r^{3}, r^{4}\right)$. U. C. L., R. I $40 b$ (Langendreer). $\times 27$ (see p. 28).

Fig. 23. Section from the same series through the apex; the four minor ribs have died out. The four major $\left(R^{1}, R^{2}, R^{3}, R^{4}\right)$ are pierced by the canopy loculi (loc.), in which the black dots, seen in two, are the vascular bundles. mc., micropyle; $b l$., 'blow-off'. U. C. L., R. I $40 a$ (Langendreer) $\times 27$ (see p. 28).

Fig. 24. Longitudinal section through the same seed as in Fig. 26. Micropyle (mc.) showing the concave upper edges of the major ribs $\left(R^{1} e, R^{3} e\right)$. The lagenostome $(l g$.$) is cut tangentially.$ o.g., pollen-grains; $p l$., plinth; $p l . j$., plinth jacket ; s., sinus; t.s., tapetal septum; $l s$. , tissue of plinth. J. I2 (Duisburg). $\times 4^{2}$ (see p. 28).

Fig. 25. Longitudinal section of plinth and lagenostome, enlarged from Fig. 28. mc., micropyle; $m . m$., micropylar membrane, still adhering to the testa; $l g$. , lagenostome with cells preserved on the left; $p l$. , plinth cavity; $l s$. ., lens, slightly displaced; p.g., pollen-grains. J. 9 (Duisburg). $\times 100$ (see p. 30 ).

Fig. 26. The same section as Fig. 24, through micropyle $(m c$.$) , showing mucronate apex of$ seed. $\quad R^{1}, R^{3}$, major ribs ; m.co., micropylar cone; s., sinus. J. I a (Duisburg). $\times$ I 7 (see p. 28).

Fig. 27 . Oblique transverse section near base of seed, showing the four vascular bundles (v.b.) corresponding to the major ribs $\left(R^{1}, R^{2}, R^{3}, R^{4}\right)$, minor ribs $\left(r^{1}, r^{2}, r^{3}, r^{4}\right)$. bl., 'blow-off'. Q. I8 (Shore). $\times 28$ (see p. 29).

Fig. 28. Same seed as in Fig. 25 , showing the lagenostome $(l g$.$) , plinth jacket (p l . j$.$) , the lens$ (ls.), plinth (pl.). J. 9 (Duisburg). $\times 25$.

Fig. 29. Longitudinal section of nucellar apex and testa, showing two loculi (loc.) of major ribs, 'blow-off' layer (bl.), lagenostome (lg.). pl.j., plinth jacket; $p l$. , plinth; s., sinus; $l s$. , lens ; $p d$. pad of tissue on tapetal septum. J. 3 (Duisburg). $\times 7^{2}$ (see p. 29).

Fig. 30. Nearly longitudinal section passing out through two major ribs at the apex in which the loculi are cut obliquely $(l o c$.$) ; the lens (l s$.$) is seen in position with the descended pad (p d$.$) .$ bl., 'blow-off'; v.b., vascular bundle; $p l . j$. , plinth jacket; s., sinus; $l g$., lagenostome; pl., plinth. J. 3 (Duisburg). $\times$ I 7 (see p. 30 ).

Fig. 3I. Section tangential to seed and doubly oblique. The upper lateral ribs $\left(r^{1}, R^{2}\right)$ are rendered obtuse, the terminal ribs $\left(R^{1}, r^{2}\right)$ are exaggerated, and the basal laterals $\left(r^{3}, R^{4}\right)$ have become cuspidate, through the plane of section. v.b. ${ }^{2}, v . b{ }^{3}, v . b^{4}$, vascular bundles; $b l$. ., 'blow-off'; pl.j., plinth jacket. J. 6 (Duisburg). $\times 17$ (see p. 30 ). 

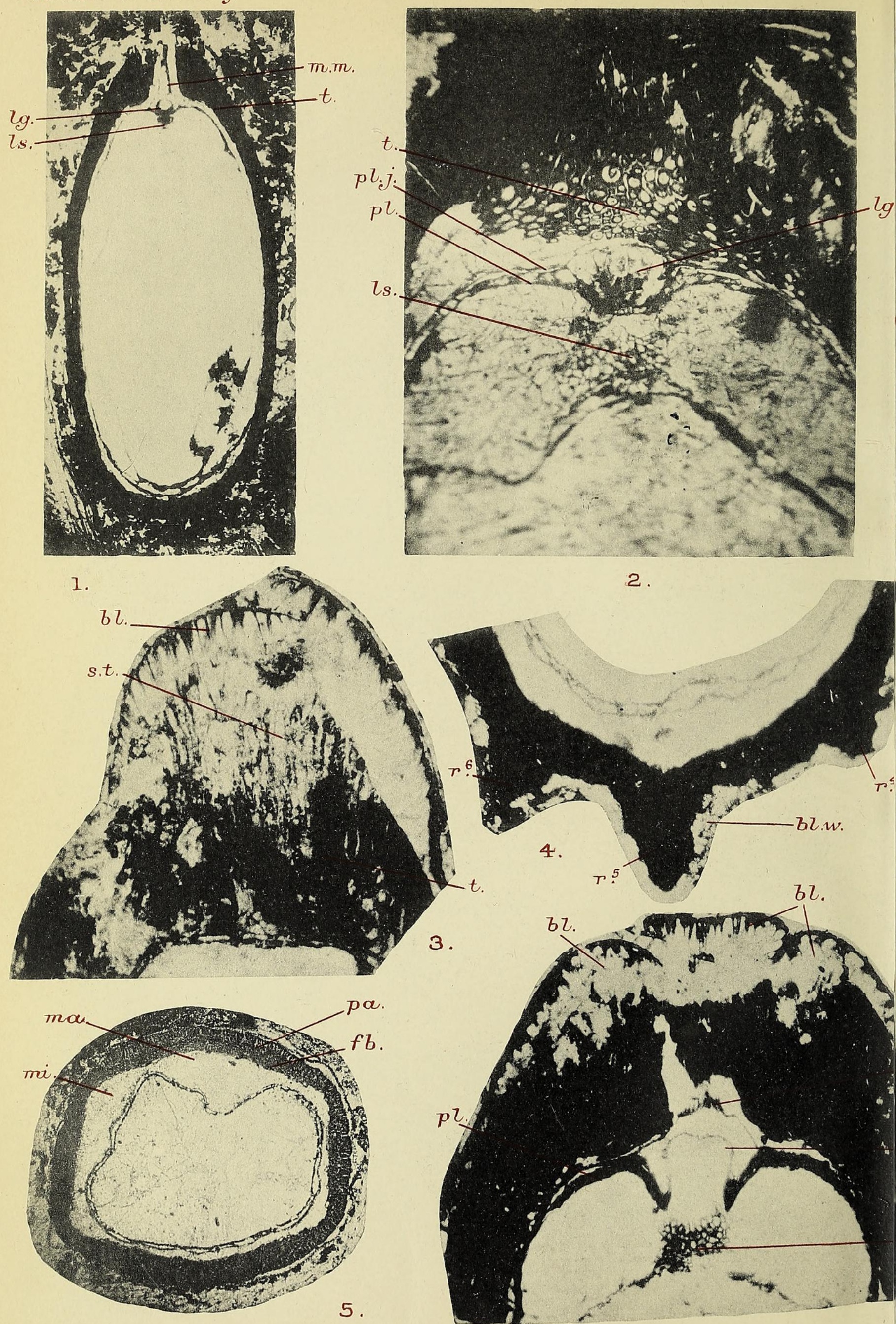
Vol.XXV,PZ.I.

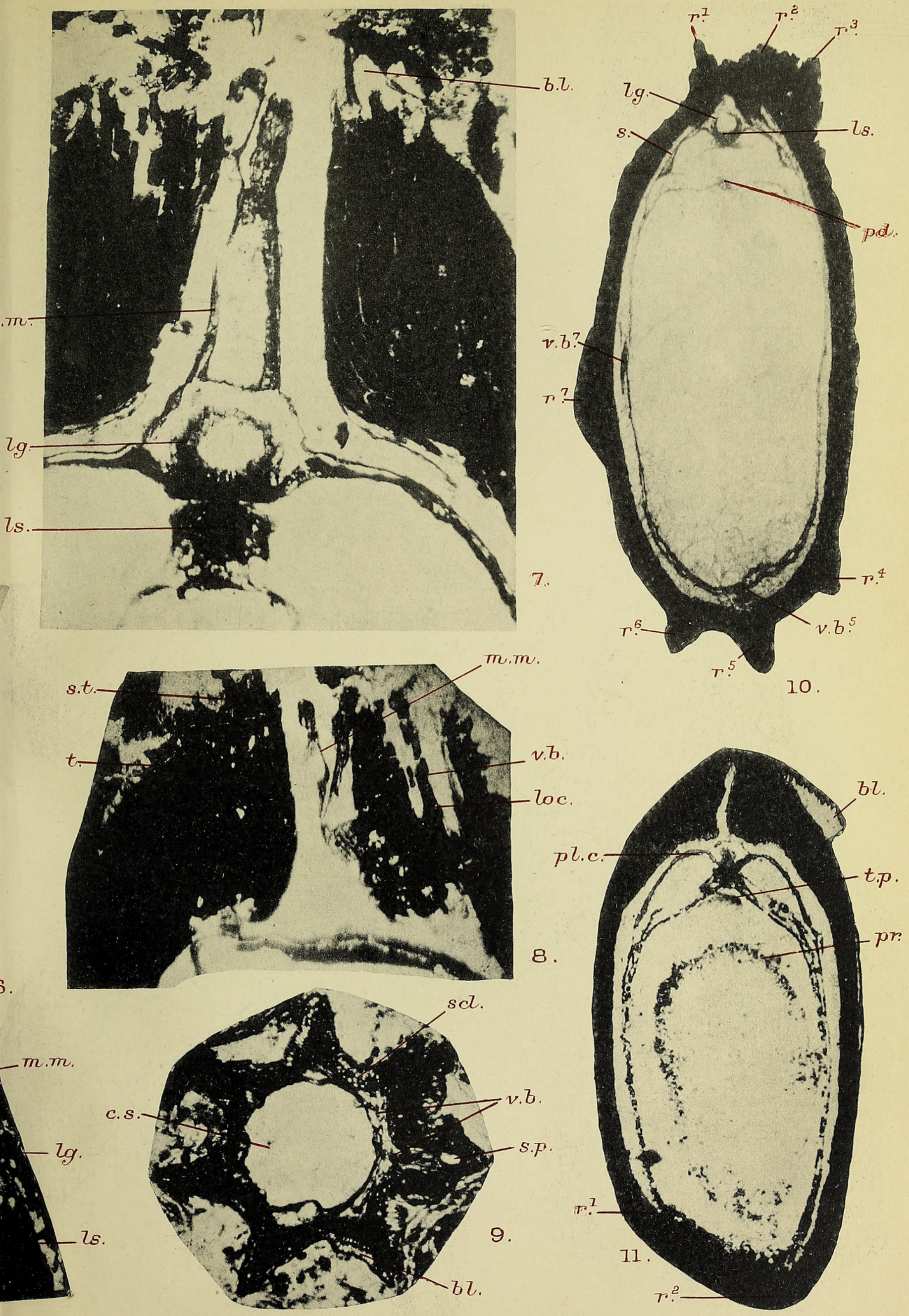




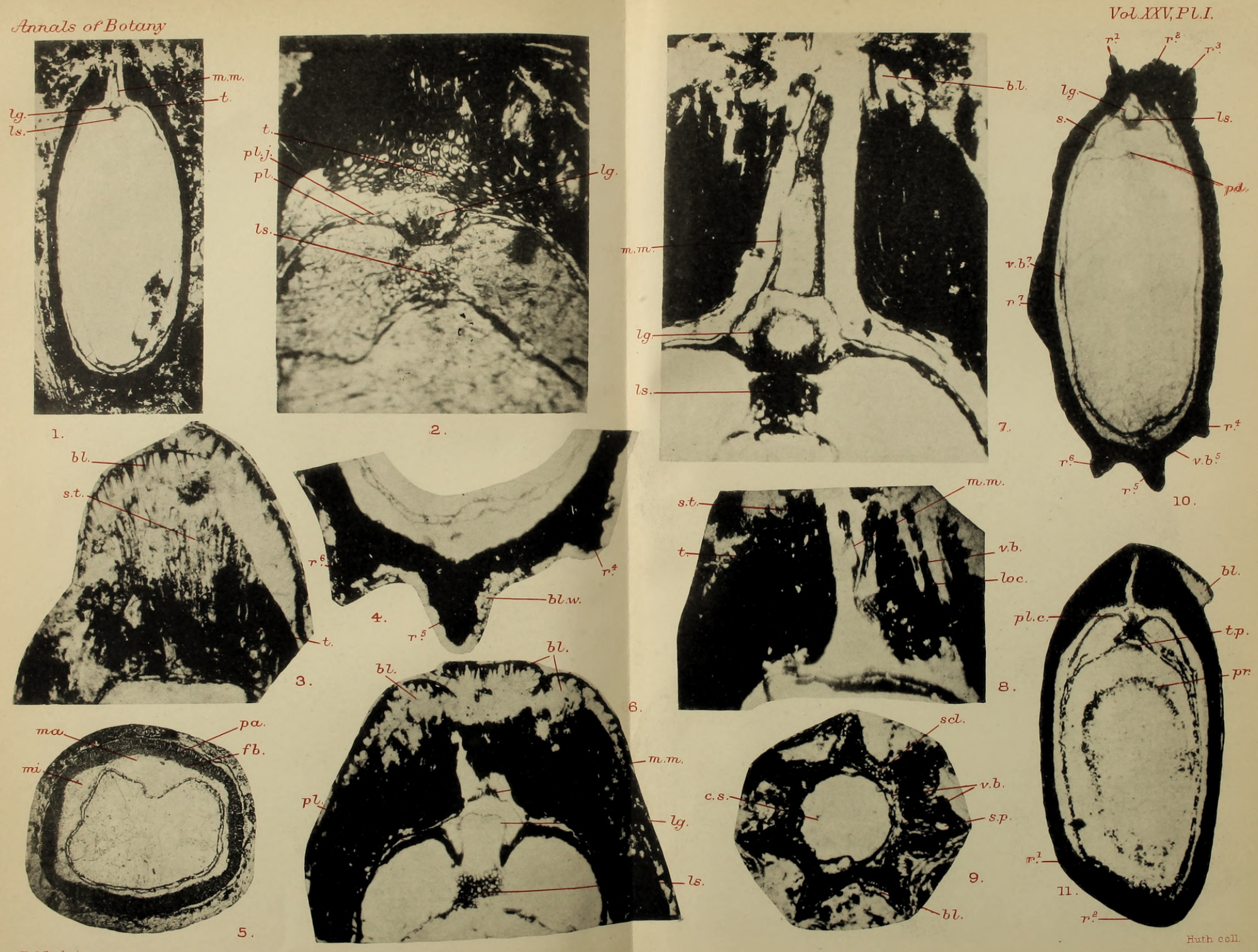


Annals of Botany.
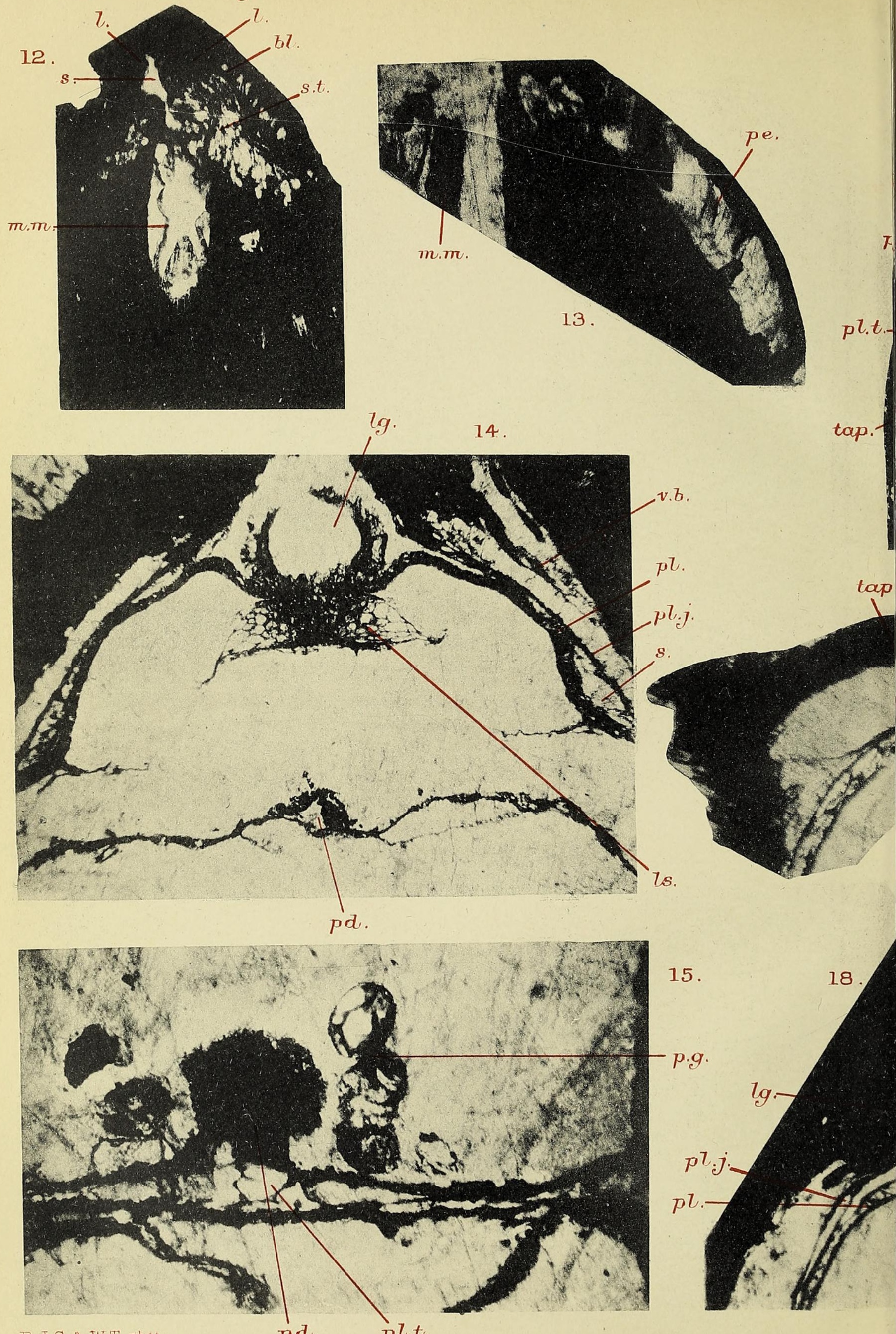


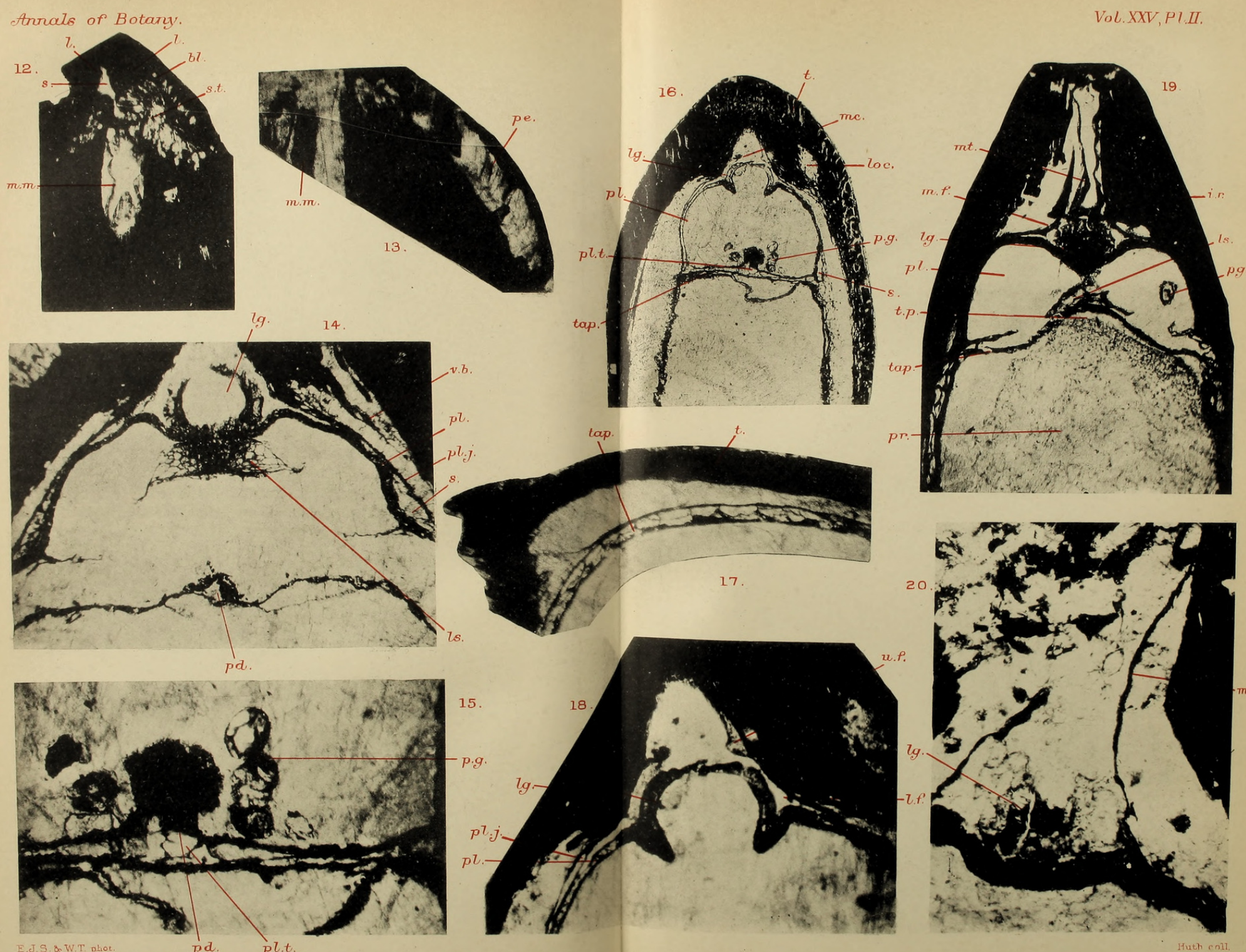


Anrats of Botany


24 .
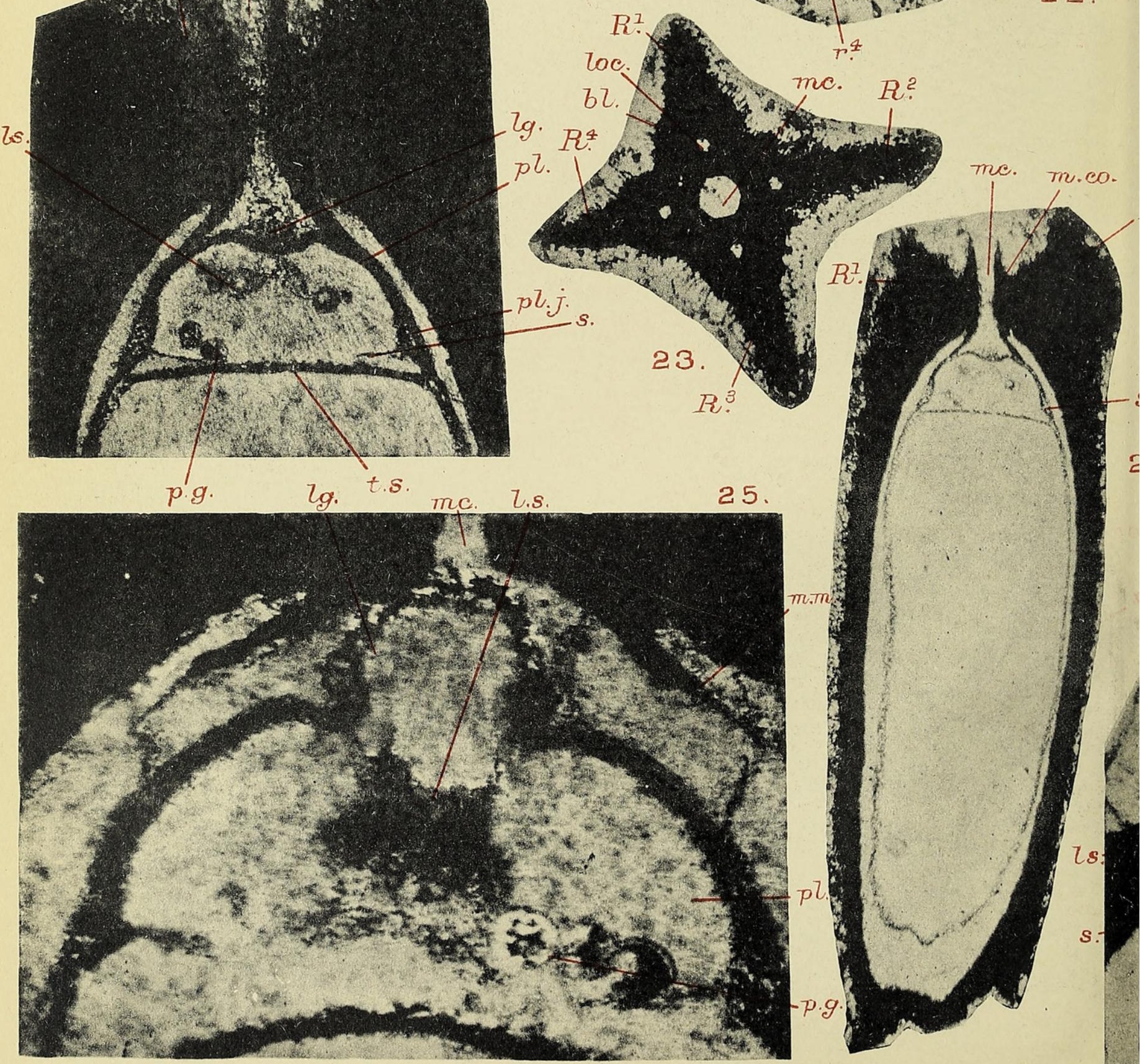


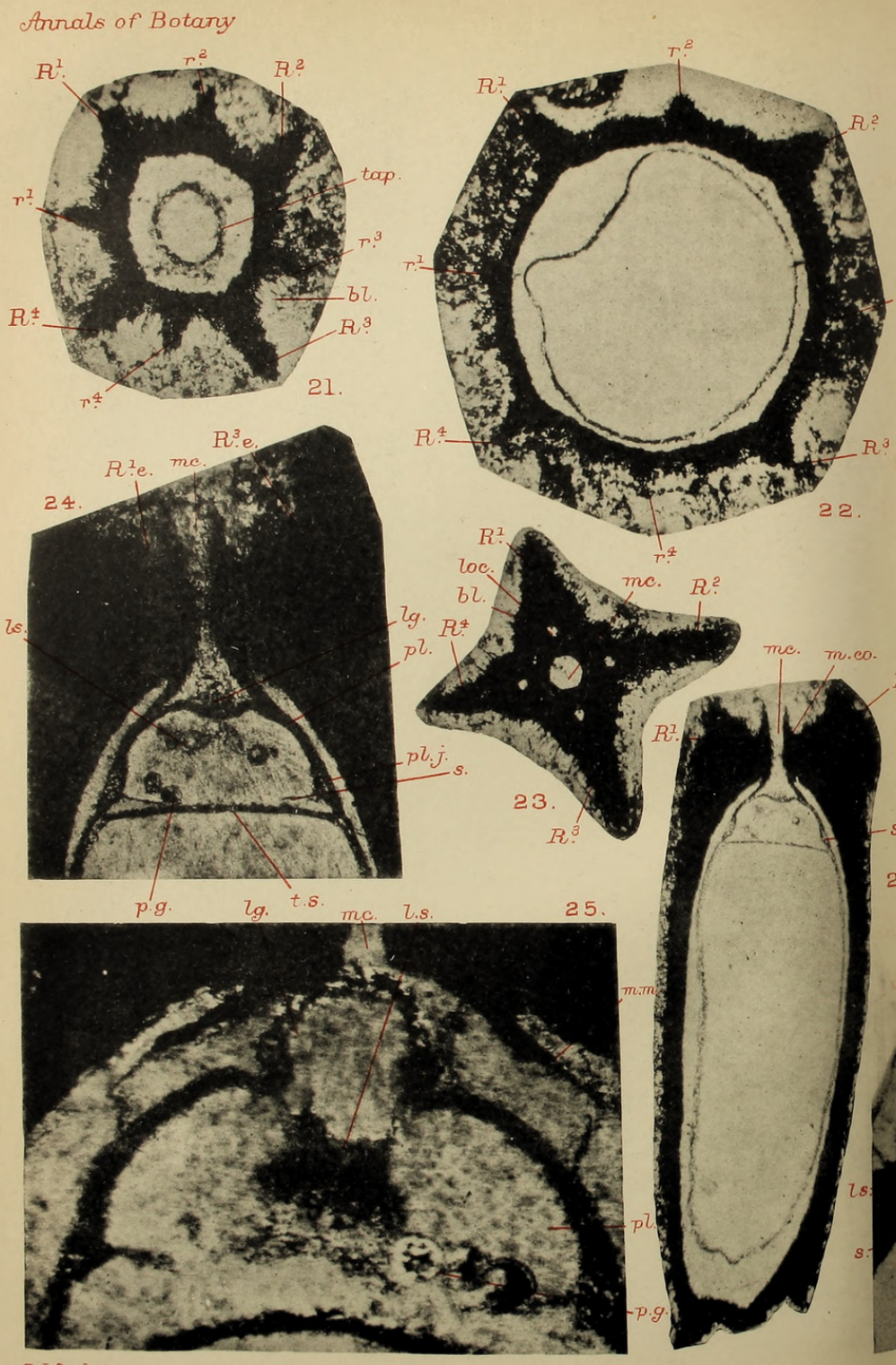

Vol. XXV,PlIII.
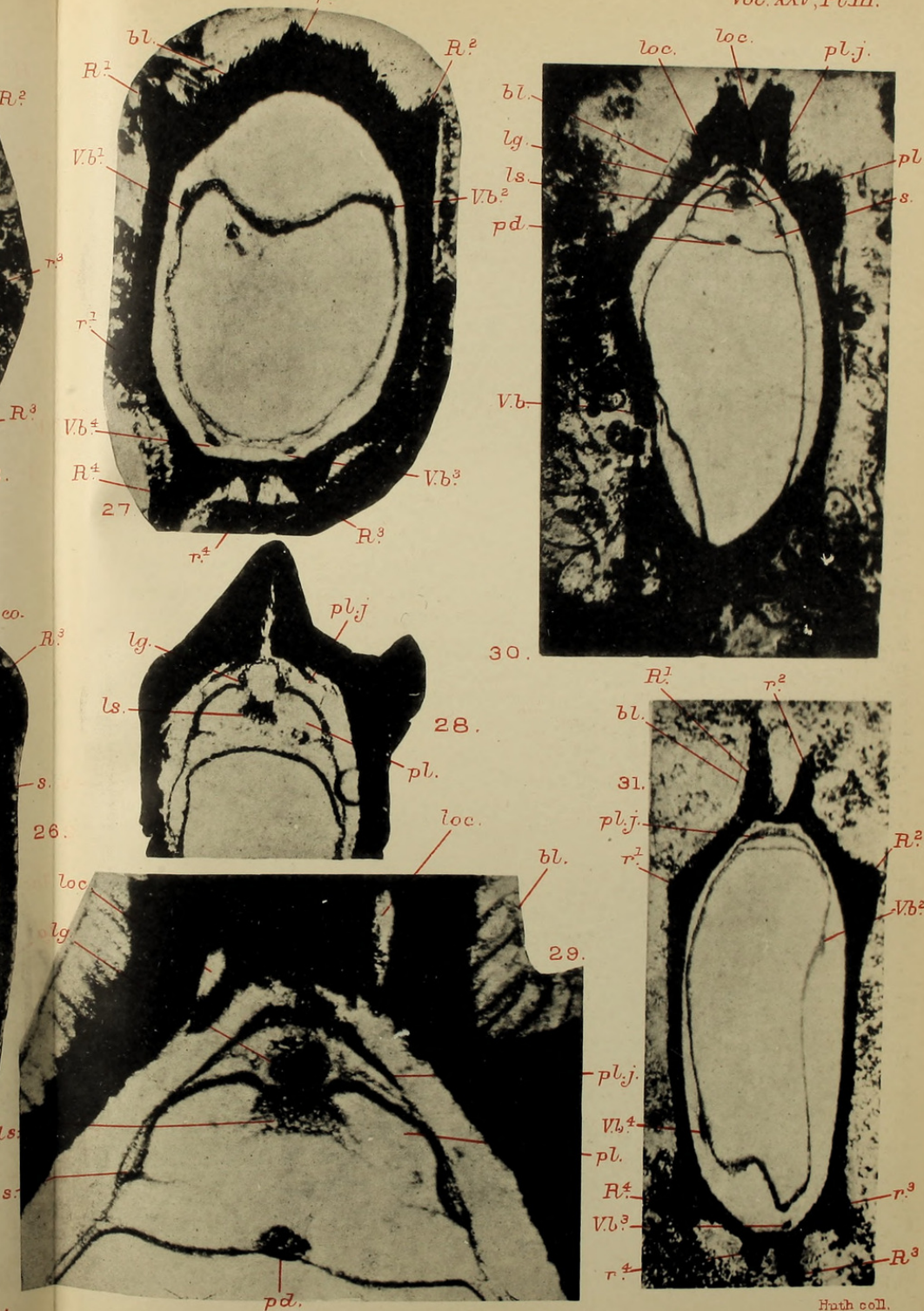

OLIVER \& SALISBURY - CONOSTOMA ANGLO-GERMANICUM 


\section{$2 \mathrm{BHL}$ Biodiversity Heritage Library}

Oliver, Francis Wall and Salisbury, E.J. 1911. "On the structure and affinities of the palaeozoic seeds of the Conostoma group." Annals of botany 25, 1-50. https://doi.org/10.1093/oxfordjournals.aob.a089309.

View This Item Online: https://www.biodiversitylibrary.org/item/236971

DOI: https://doi.org/10.1093/oxfordjournals.aob.a089309

Permalink: https://www.biodiversitylibrary.org/partpdf/319817

\section{Holding Institution}

Smithsonian Libraries

\section{Sponsored by}

Biodiversity Heritage Library

\section{Copyright \& Reuse}

Copyright Status: Not in copyright. The BHL knows of no copyright restrictions on this item.

This document was created from content at the Biodiversity Heritage Library, the world's largest open access digital library for biodiversity literature and archives. Visit BHL at https://www.biodiversitylibrary.org. 